\title{
Araştırma Makalesi / Research Article \\ Perakende Market Lokasyonları için CBS Tabanlı Çok Kriterli AHP Yöntemi ile Optimal Yer Seçimi Analizi: İstanbul Örneği
}

\author{
Hasan Can BEYHAN ${ }^{1 *}$, Gizem EREN², Bahadır AKTUĞ ${ }^{3}$ \\ ${ }^{1}$ Başarsoft Bilgi Teknolojileri A.S.., Ankara \\ ${ }^{2}$ Başarsoft Bilgi Teknolojileri A.Ş., Ankara \\ ${ }^{3}$ Ankara Üniversitesi, Mühendislik Fakültesi, Jeofizik Mühendisliği, Ankara
}
Sorumlu yazar e-posta ${ }^{1}$ hasan.beyhan@basarsoft.com.tr. ORCID ID: https://orcid.org/0000-0003-1920-4516 ${ }^{2}$ gizem.eren@basarsoft.com.tr. ORCIDID: https://orcid.org/0000-0001-5388-563X ${ }^{3}$ aktug@ankara.edu.tr. O ORCID ID: https://orcid.org/0000-0002-7995-4477

Geliş Tarihi: 01.10.2020 Kabul Tarihi: 14.12.2020

\begin{tabular}{cl} 
& Öz \\
\cline { 2 - 3 } Anahtar kelimeler & Potansiyel zincir market yerlerinin optimal olarak seçilmesi hala ilgi gören bir konudur. Yeni açılan \\
Grid Bazlı Yer Seçimi; & marketlerin önemli bir bölümü düşük karlılık ve Pazar yamyamlığına maruz kalmaktadır. Karlılığı yüksek \\
Coğrafi Bilgi Sistemi & yöntemlerin, kişisel deneyim ve içgüdülere dayalı geleneksel yöntemlere göre daha etkin olduğu ortaya \\
(CBS); Önemli Noktalar & konmuştur. Diğer yandan, veri setinin ölçeği büyüdükçe, olası tutarsızlıkların olma ihtimali artmaktadır. \\
(POI); Perakende Zincir & Bu çalışmada, İstanbul'daki zincir market yerlerinin seçimi için mevcut en büyük CBS veri seti kullanılmış \\
Marketler; Analitik & ve tüm veri seti için kapsamlı bir tutarlılık analizi gerçekleştirilmiştir. 23 adet öznitelikten oluşan geniş \\
Hiyerarşi Süreci (AHP); & bir veri kümesi çalışmada girdi olarak kullanılmış ve optimal market yerlerinin belirlenmesinde Analitik \\
Coğrafi Karar Destek & Hiyerarşi Süreci (AHP) kullanılmış ve sonuçlar İdeal Çözüme Benzerlikle Tercih Düzeni Tekniği (TOPSIS) \\
Sistemi (GeoKDS). & yöntemi ile de doğrulanmıştır. Sonuçlar, mevcut 7196 market yerinden 218'inin analizler sonucunda \\
& yüksek potansiyelli olarak tespit edilen lokasyonlarda yer aldığını, bununla birlikte tespit edilen 75 \\
& yüksek potansiyelli alanda hala yeni market açılması için potansiyel olduğunu göstermektedir.
\end{tabular}

\section{Optimal Location Selection for Retail Market Locations with GIS Based Multi Criteria AHP Method: The Case of Istanbul}

\footnotetext{
Keywords

Grid Based Location

Selection; Geographic

Information System

(GIS); Points of Interest

(POI); Retail Chain

Markets; Analytical Hierarchy Process

(AHP); Geographical Decision Support

System (GeoKDS).
}

\begin{abstract}
Optimal selection of possible chain market locations is still an ongoing interest. A significant number of newly founded markets are suffering from low profitability and cannibalism. Contrary to the traditional methods which are based on personal experience or instincts, quantitative methods which employ Geographic Information Systems (GIS) and large data sets have proved to be more efficient to determine the most profitable and market locations. On the other hand, the larger the scale of the data set, the more prone it is to possible inconsistencies. In this study, we employ the largest available GIS data set for selection of chain market locations in İstanbul and carry out an extensive consistency test for the whole data set. A wide range of 23 attributes were incorporated into the analysis and Analytical Hierarchy Process (AHP) was used to determine the optimal locations. The results were also confirmed by the Technique for Order Preference by Similarity to Ideal Solution (TOPSIS) method. The results show that 218 out of 7196 markets are already located high potential areas determined in the analysis and there is still a potential to establish new markets in 75 high potential areas according to our analysis.
\end{abstract}

(C) Afyon Kocatepe Üniversitesi

\section{Giriş}

Günümüzde artan nüfusun yarattığı talep sorunu birçok sektörde gözle görülür şekilde talep artışına neden olmaktadır. Bu sektörlerden birisi de perakende market sektörüdür. Artan nüfus ve şehirleşme sırasında oluşan talep artışı nedeniyle firmalar en optimal biçimde süreçlerinde iyileştirmeye giderek maliyetlerini azaltmaya çalışmaktadırlar. Talep artışı ile birlikte şehirlerdeki 
market sayıları gittikçe artmakta ve tüketiciye ulaşılabilirlik konusunda birçok sorun ortaya çıkartmaktadır. Perakende marketler günümüzde sadece gıda tedariki değil bir evin tüm ihtiyaçlarını karşılama konusunda kendilerini ve tedarikçilerini geliştirmişlerdir. Büyüyen şehirlerde artan taleple birlikte sektörde çok sayıda firma hizmet vermektedir.

Türkiye'de market sektörü Ocak 2018'den itibaren ilk 9 ayda 2,517 adet yeni market sayısı ile birlikte \%9 büyümüştür. 28,544 olan market sayısı 2018' in ilk 3 çeyreğinde 31,061'e yükselmiştir (Int Kyn. 1). Türkiye Alışveriş Merkezleri ve Perakendeciler Federasyonu (TAMPF) ve Türkiye Odalar ve Borsalar Birliği (TOBB) raporuna bakıldığında ise genişleme hacminin hedefleri ortaya konularak, Türkiye'de perakende market ve alışveriş merkezi (AVM) istihdam sayılarının 2023 yılında hedef olarak şu anki durumun 2 katına erişeceği, mağaza sayılarının toplamda 84,000 adet olacağı ve istihdam sayısının 1 milyon üzerine çıkacağı öngörülmektedir (TAMPF 2016).

Son yıllarda perakende sektörü, yerel ve yabancı yatırımların da eklenmesiyle büyük ölçüde gelişmekte ve büyümektedir.

Perakende sektörde, özellikle gıda ürünleri, Dünya'da 2020 Mart' ta ortaya çıkan Covid-19 etkileri ile de etkilenerek tüketicileri en yakınlarındaki markete ve mobil uygulamalar ile online satışa yönlendirmiştir. Covid-19 sürecinde yaşananlar nedeni ile insanlar market alışverişlerini yoğunlaştırmışlardır. Online sipariş veren müşterilerin siparişini zamanında teslim edebilmeleri için mağazanın konumu yine önem kazanmaktadır. Perakendeciler ve alışveriş merkezleri için artan perakende ürünleri talebi için konum yönetimi sayesinde maliyetlerin azalması ve böylece daha yüksek karlar getirebildiği düşünülmektedir.

Perakende market firmaları için yer seçimi, stratejik ve geri dönüşü maliyetli olan bir karar olduğu için, firmalar yer seçimi yaparken nüfus, rekabet ve ekonomik özellikler gibi birçok kriteri değerlendirmek durumundadırlar (Karadeniz 2009). Tüm bunlara ek olarak işletmelerin rakiplerine yakın olması da önemli derecede etki yaratmaktadır. Coğrafi talep ve coğrafi rekabet birlikte analiz edilerek yeni bir perakende market için yer seçimi tanımlanabilir. Bir mağaza açıp açmamaya karar verme, birçok kriteri devreye sokarak olasılıklar listesinden en uygun konuma karar verilmesidir (Wood and Reynolds 2012).

Kâr marjına yansıyan bu durum firmanın birbirine yakın kendi şubeleri arasında gerçekleşen Pazar yamyamlığı (Cannibalism) tanımını ortaya çıkarmakta ve firmalara zarar vermektedir (Merunka 2010). Perakende sektörü, kolayca erişilebilen ve ürünlerini maksimum sayıda müşteriye sunabileceği yerleri seçmektedir. Rekabet, perakende sektörü için en önemli yer seçim kriterlerinden biridir (Kayacan ve Yirmibeşoğlu 2017). Bu nedenle firmaların yer seçimi konularında çalışmaları ve teknoloji yatırımları artmaktadır. Yer seçimi konusu perakende marketlerin artan şube sayısından oluşan rekabet, cannibalism ve tüketicilerin ihtiyaçlarına maksimum yanıt vermede çok önemlidir.

Günümüzde firmalar, yer seçimi kararlarının "vermeleri gereken en önemli karar" olduğunun ve bunu yaparken de bilimsel yollara başvurmaları gerektiğinin farkındadırlar (Ladle et al. 2009).

Yer seçimi ilk olarak 1950'lerde Amerika Birleşik Devletleri $(A B D)^{\prime}$ de hükümet projelerinde kullanılmıştır. Bunun ardından, yer seçimi tüm sektörlere yayılmıştır. Yayılan sektörlerde firmalar kendi yer seçim kriterleri ve yöntemlerini geliştirmişlerdir. Yer seçimi kavramı karlılığı artırmak ve ticari yönetimi sağlamak için kullanılmaktadır. Perakende market firmalarının piyasada rakiplerine göre hayatta kalabilmesi için yer seçimi yapması çok önemlidir. Firmalar bu yüzden taleplerini, müşteri ihtiyaçlarını ve tahminlerini kullanarak en uygun yeri seçerler. (Kayacan ve Yirmibeşoğlu 2017).

Perakende marketler için iyi bir yer seçimi hedef pazar, rakipler ve maliyetlerle ilişkilidir. Aynı zamanda çevre koşullara göre de etkilenmektedir. Uygun rakipler, yeterli park yerleri ve trafik gibi başka koşullar da bu seçime etki etmektedir. Müşteriler kolay ulaşım imkânı bulunan mağazaları tercih etmektedirler (Karadeniz 2009).

Müşteri tercihindeki en belirgin kriter markete ulaşmaktır. Perakende marketlerin, nüfusun daha yoğun ve ulaşımın daha kolay olduğu yerlerde bulunması gerekmektedir (Şentürk vd. 2017). 
Perakende marketler için yer seçimi; firmalar için finansal ve kurumsal imaj riskleri oluşturabilmesinden (Alarcon 2011), kentsel alanlarda perakende ağı bulma ve uygun yer seçimi sağlayabilmesinden (Roig-Tierno et al. 2013) ve yeni mağazaların açılacağı optimal yerlerin belirlenmesinden dolayı uygun analizi yapmak adına çok önemlidir (Hernández and Bennison 2000).

Firmalar yer seçimi konusunu, gelişen teknolojiler sayesinde bilgi sistemleri ile yönetmeye çalışmaktadırlar. Dünya'da Coğrafi Bilgi Sistemi (CBS)'de bu bilgi sistemlerinden en önemlisi ve tercih edilenidir. CBS kullanımının yaygınlaşması ve yer seçimlerindeki etkililiği de buna destek olmaktadır (Kayacan ve Yirmibeşoğlu 2017).

CBS sözel ve koordinatlı verileri yönetebilme ve sunabilme özelliği sayesinde mühendislik, işletme, iktisat, yer bilimleri vb. birçok alanda kullanılan ve bu alanlardaki verileri baz alarak oluşturulan karar destek sistemleri sayesinde karar vericilere destek olan bir bilgi sistemidir. CBS teknolojileri sayesinde satış ve zaman analizleri, pazarlamaya ait müşteri ve pazar araştırmaları, ticaret alanları gibi pek çok konu analiz edilmektedir. CBS, Çok kriterli yer seçiminde karmaşık yapıdaki verilerin değerlendirilmesinde hızlı ve etkili bir şekilde kullanılmaktadır. (ŞAHiN 2010).

Perakende marketler için uygun yerin belirlenmesinde CBS teknikleri kullanılarak yapılan çalışmalara bakıldığında; veri görselleştirme karar alma sürecinde (Musyoka et al. 2007), teknik bilgiye sahip olmayan yöneticiler için bilgileri daha kolay anlamalarında ve kritik olan kararları almalarında (Ozimec et al. 2010), dijital haritaların ilişkisel veri tabanları ile ilişkilendirilerek karar alma süreçlerinin etkin hale gelmesinde (Mendes and Themido 2004), CBS araçlarının kullanımına dayalı özel araçlar sayesinde hız ve verimliliğin artmasında (Wood and Reynolds 2012) ve en uygun yerin optimal tespitinde (Mendes and Themido 2004) yardımcı olmaktadır. Günümüzde yer seçimi analizi CBS sistemi kullanılarak yaygınlaşmaktadır. Bu kapsamda birçok farklı sektörde çalışmalar yapılmaktadır. Enerji sektöründe güneş enerji santrallerinin, rüzgâr santrallerinin, uygun trafo yerlerinin seçimleri gibi çalışmalarda, bankacılık sektöründe ATM, şube vb yer seçiminde, AVM, market, eczane gibi diğer konularda da yer seçimi analizleri yapılmaktadır. (Bayar 2019)'da Ankara'da yaptığı alışveriş merkezlerinin kuruluş yerlerinin tespiti için CBS kullanılarak gerçekleştirilen analizler doğrultusunda, doğru planlama ile en uygun yerler seçilmiştir (Bayar 2019). Rüzgâr türbinleri için, rüzgâr enerjisi üretimi ile büyük potansiyele sahip olan Çanakkale ve Balıkesir bölgelerinde CBS kullanılarak yer seçimi sonuçları hesaplanmıştır (Atici vd. 2015). Güneş Enerjisi Çiftliklerinin uygun alanının belirlenmesi için, CBS ve Analitik Hiyerarşi Süreci (AHP) yöntemi kullanılarak güneş enerjisi çiftlikleri için en uygun yer seçimi çalışması yapılmıştır. (Uyan 2013). Özel bir bankaya ait ATM'ler için Kayseri ili içerisinde ATM'lere ait veri setleri kullanılarak gerçekleştirilen veri kümesinden kural bazlı bir karar destek modeli oluşturarak yer seçimi yapılmıştı (Zeydan ve Kayserili 2019). Spor bahis bayileri için uygun yerin belirlenmesi kapsamında yine CBS ortamında çok kriterli yer seçimi analizi sayesinde uygun kriterli yerler haritalı sonuçlar üretilmiştir. (Şentürk vd. 2017).

Yer seçimi analizinin farklı dallarda çalışmalarının ardından perakende market zincir noktaları ile ilgili yapılan çalışmalar tarandığında ise birçok farklı çalışma ortaya çıkmaktadır. Çin'in Guiyang eyaletinde 2018 yılında yapılan çalışmada 18 sosyoekonomik kriter baz alınmış ve küçük perakende mağazalar için yer seçimi sayesinde mekansal erişilebilirlik değerlendirmesi ve pazar potansiyeli tahmini olan iki aşamalı hibrit bir model önerilmiştir. Bu modele göre hedef bölgelerin mekansal erişilebilirliği ve perakende mağazaların bulunmadığı bölgelerin belirlenmesi sağlanmıştır. íki aşamalı model, pazar potansiyeli en yüksek ve rekabeti düşük alanları belirlemiştir. Önerilen model, perakende zincirlerini, iş yeri planlamasının geliştirilmesini ve bölgesel kalkınma politikalarının formüle edilmesini yönlendirmiştir. Bu çalışma CBS üzerinden kriterler belirlenerek ve kullanılan kriter ve veri seçimleri mevcut eyalet ve ülke yapısı göz önünde bulundurularak yapılmıştır (Wang et al. 2018). İspanya'nın Murcia şehrinde 2013 'de yapılan bir başka çalışmada ise perakende market satış yeri konumu seçme süreci için CBS ve AHP yöntemini birleştiren bir metodoloji ile yapılmıştır. Bu çalışma bir süpermarket için başarı faktörlerinin konumu ve 
rekabetiyle ilişkili olduğunu göstermektedir. Sonuçlar, bir süpermarketin başarısının \%75' inin; geçen ticaret hacmi alanın görünürlüğü, bir süpermarket ve rakipleri arasındaki mesafe ve potansiyel ile açıklandığını ortaya koymuştur. Çıkan bulgulara dayanarak en önemli faktörlerin yer ve rekabet ile ilgili olduğu sonucuna varılmaktadır. Yapılan çalışma bina verileri üzerinden hesaplanmıştır. Ancak Türkiye'deki verileri göz önüne alındığında bina verilerinin sağlıklı olmayışı böyle bir çalışmanın yapılmasına engel olmaktadır (Roig-Tierno et al. 2013). 2002 yılında ise bulanık AHP algoritmaları kullanılarak yapılan çalışmada, marketler için yer seçim karar destek modeli ile örneklenen mağazaların orijinal tarihsel verilerini değiştirmede, mesafe ve rekabet faktörlerini içeren veri işleme prosedürlerinin tahmin doğruluğunu gerçekten ileri taşıdığı doğrulanmıştır. Ancak bu çalışma sadece kriter seçimlerinin nasıl olacağı ve mevcuttaki geleneksel yöntemlerin tartışmaları ile daha çok kriter belirlemedeki süreçlerden bahsetmiştir (Kuo et al. 2002). 2012 yılında İspanya'nın Gran Canaria adalarını baz alan bir bölgede sadece tek bir tesisin bulunması gereken bir dağıtım sisteminde, çatışan hedefler arasında belirli bir denge kurulması amacı ile karar verme araçları oluşturması amaçlanmıştır. Bu sayede rekabetçi konum modelleri ve CBS araçları kullanılmıştır. Hem pazar payını temsil eden hem de pazar yamyamlığı (cannibalism) etkisini gösteren bir harita sağlamak üzere çalışılmıştır. Çalışmaya yasak bölgeler ve diğer kısıtlar dahil edilerek yeni bir tesis açıldığında oluşan etkiler CBS harita teknikleri kullanılarak görselleştirilmiştir. Çalışma bölge bazlı yapılmış ve Gran Canaria koşulları altında gerçekleştirilmiştir (Suárez-Vega et al. 2012). 2010 yılında ülkemizde perakende market sektörü için şube yer seçimi problemine yönelik örnek bir uygulama yapılmıştır. İstanbul'un Pendik ilçesinin 14 mahallesi pilot bölge seçilerek bu bölgede hizmet veren bir perakende şirketinin açacağı 5 yeni şube için en uygun yer seçimi analizi yapılmıştır. Bu uygulama kapsamında nüfus, ekonomi ve yerleşim verileri kullanılarak uzaklık, nüfus yoğunluğu ve yola yakınlık gibi önemli kriterler yardımıyla market alanları belirlenmiştir. Çalışmada CBS teknolojilerinin karar destek sistemlerindeki önemi ve avantajları vurgulanmıştır.
Ancak çalışma kapsamı 2010 şartlarına göre değerlendirilmiş ve küçük bir örneklem üzerinden az sayıda kriter ve veri ile gerçekleştirilmiştir.

(ŞAHIN 2010).

Bu çalışmada ise, benzer çalışmalar ve perakende market zincir noktalarının yer seçiminde kullanılan kriterlerler literatürden taranmıştır. Literatür taraması sonucunda belirlenen kriterlere ek olarak Türkiye'deki veri bulunabilirliği göz önüne alınarak kriter sayısı ve niteliği artırılmıştır. Kriterler talep kapasitesi, harcama kapasitesi, ulaşım kolaylığı, düşük rekabet, merkezi konum ve diğer önemli noktalara yakınlık olarak belirlenmiştir. Belirlenen kriterler için veriler nüfus artışı, nüfus yoğunluğu, pazar yayılımı ve şehrin büyüme kapasitesi göz önüne alınarak ìstanbul ilinde yapılması kararlaştırılmıştır. CBS yardımı ile oluşturulmuş olan "GeoKDS (Coğrafi Tabanlı Çok Kriterli Mekansal Karar Destek Sistemi)" web uygulaması sayesinde belirlenen veriler kapsama (coverage) hesabı ile İstanbul ili sınırlarında kalan gridlere işlenmiştir. İşlenen veriler sınıflandırılarak literatür taraması sonucu karar verilen çok kriterli AHP yöntemi ile önem derecesine göre uzmanlar tarafından matrislerle puanlanmış ve gridlerin optimal yer seçimi için toplam puanı hesaplanmıştır. Bu çalışma kapsamında kullanılan 23 farklı öznitelik, ülkemizde yapılan bu tür analizlerin en kapsamlısı olarak gerçekleştirilmiştir. Ayrıca puanlamalar TOPSIS metodu üzerinden tekrar analize sokularak doğrulanmış ve test edilmiştir. Veri kümesinin artması, veri tutarlılıklarının da daha iyi kontrol edilmesini gerektirmektedir. Kullanılan yöntemin her aşamasında, tutarlık oranı ve tutarlık endeksleri hesaplanarak, nihai sonuçların duyarlığı kontrol edilmiştir. Sonuç olarak hesaplanan toplam puanlar grid bazlı tematik haritalarla görselleştirilmiştir. Görselleştirilen sayısal coğrafi veri üzerinden mevcut perakende market zincir noktaları ile karşılaştırılma yapılmış bu sayede mevcut market zincir şube konumları ve çıkan sonuçlar kıyaslanmıştır. Sonuçlara bakıldığında 75 adet gridin yeni market zincir noktası açmak için yüksek potansiyelli olduğu ve mevcut marketlerin şu andaki pazar payı göz önüne alındığında \%3 ‘ünün çalışma kapsamında yüksek potansiyelli yerlerde hizmet verdiği tespit edilmiştir. Bu sayede karar vericilere 
analizin dinamik yapısı sayesinde yeni zincir market açmada yardımcı olması, rakiplere göre mağaza konumlandırmada ve mevcut şubelerin Pazar yamyamlı̆̆ı (cannibalism) açısından arındırılmasına, sonuçların mevcut i̇stanbul zincir market potansiyelini ortaya koyarak yeni şube açımında kullanılacak grid bazlı tematik haritaların oluşturulması sağlanmıştır.

\section{Yöntem}

Önemli ve geri dönüşü zor olan seçimler için yalnızca sezgisel olarak alınan kararlar yeterli olmamaktadır. Karar verme problemi, birçok seçenek içerisinden bir amaca göre en uygun seçeneğin belirlenmesidir (Saaty 1994). 1960'lı yıllarda karar verme problemlerini basite indirgeyecek çok kriterli karar verme yöntemleri geliştirilmeye başlanmıştır (Wind and Saaty 1980).

2019 yılında yapılan bir çalışmada yer seçimi problemlerinin en çok, çok kriterli problemler ile çözüldüğü ortaya konulmuştur (Zeydan ve Kayserili 2019). Yapılan literatür taramaları, çok kriterli problemlerin ise en çok AHP yöntemi kullanılarak çözüldüğünü ortaya koymaktadır. Problemimizin çok kriterli yapısı ve bu yapının AHP yöntemi ile kolay eşlenebilmesi nedeni ile AHP yöntemi seçilmiştir. CBS üzerinde daha verimli olması, yazılıma kolay aktarılıyor olması ve diğer başka çalışmalarda yoğunlukla kullanılıyor olması AHP yöntemini seçmemizdeki temel esaslardır.

\subsection{Analitik Hiyerarşi Süreci (AHP)}

1970'li yıllarda Thomas Saaty tarafından geliştirilen AHP Yöntemi, birden fazla kriter ile karar verme problemlerinin çözümü için geliştirilmiş bir yöntemdir (Kuruüzüm ve Atsan 2001). AHP Yöntemi, problemleri hiyerarşik bir yapıda sınıflandırarak her seviyede kriter ağırlıklandırma matrislerinin oluşturulmasıdır (Saaty 1994). AHP Yöntemi birçok alanda kullanılmaktadır. Fabrikaların yer seçimi analizi (Yang and Lee 1997), uçak seçim süreci (Dožić and Kalić 2014), rüzgâr santrali yer seçimi (Atici et al. 2015), risk analizi (Millet and Wedley 2002), uygulama alanlarından bazılarıdır.

Analitik hiyerarşi süreci (AHP), başlangıçta ortaya konan kriter ve alternatiflerle karmaşık sorunları çözmeye yönelik bir hiyerarşik model tanımlamaktan oluşur. Karmaşık problemler basit kararlara bölünerek, problemin daha basite indirgenip çözülmesi sağlanır (Arquero et al. 2009). Çok kriterli karar modeli ile perakende marketlerin açılacağı uygun yeri seçmek ve bunu önceliklendirmek mümkün hale gelmektedir. AHP yöntemi başarıyı etkileyen kriterleri belirlemektedir (Gbanie et al. 2013). Karar verme sürecinde bir ya da daha fazla çözüm belirlenerek bu süreci kolaylaştıran çok kriterli karar modelleri kullanılmaktadır (Rybarczyk and Wu 2010). AHP yöntemi üç ana adımdan oluşmaktadır (Saaty and Vargas 2001). Şekil 1 de ifade edildiği gibi, ilk adım, problemi hiyerarşik bir yapıya ayırarak bu hiyerarşiyi birkaç seviyeye bölmektir.

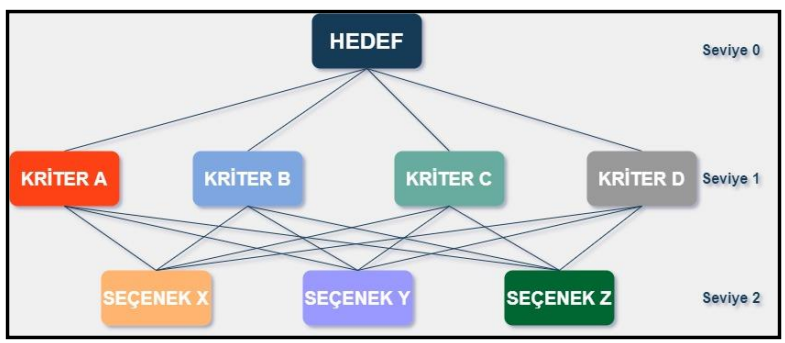

Şekil 1. AHP Yöntemi Hiyerarşik Yapısı

İkinci adım, kurulan hiyerarşinin her seviyesinde karar çizelgelerini oluşturmaktır. Matrisler, göreceli veriler kullanarak ikili karşılaştırmayı sağlamaktadır. $\mathrm{Bu}$ ikili karşılaştırma, her faktörün katkısının bağımsız olarak değerlendirilmesine izin vererek karar verme sürecini basitleştirmektedir (RezaeiMoghaddam et al. 2008). Çeşitli kriterlerin ikili karşılaştırmaları organize edilerek bir kare matrise dönüştürülmektedir. Karşılaştırma matrisi kriterlere veya alt kriterlere göre ağırlıklandırııp, alternatiflere göre derecelendirilerek göreceli önemi ortaya çıkarmaktadır (Bhushan and Rai 2004). Matrisin tutarlılığı değerlendirilerek bu tutarlılık endeksi bir eşik seviyesine ulaşamazsa, karşılaştırma cevapları yeniden incelenmektedir (Şener vd. 2010). Temel olarak hedef, kriterler ve alternatiflerden oluşmaktadır. Kriter ve alternatiflerin ikili karşılaştırılması ve bu karşılaştırmanın nümerik olarak puanlanmasına dayanmaktadır. Puanlama birçok yöntem ile yapılabilmektedir. Ancak temel olarak Çizelge 1'deki yapıya literatürde rastlanmaktadır (Saaty 2008). 
Çizelge 1. Kriterlerin Göreceli Yargılarının Karşılaştırma Puanı Çizelgesi (Saaty 2008)

\begin{tabular}{ll}
\hline Skor & Yargılar \\
\hline 1 & Eşit önem \\
\hline 2 & Zayıf veya Hafif Önem \\
\hline 3 & Orta Önem \\
\hline 4 & Orta Üstü Önem \\
\hline 5 & Güçlü Önem \\
\hline 6 & Güçlü Üstü Önem \\
\hline 8 & Çok Güçlü Önem \\
\hline 9 & Çok Çok Güçlü Önem \\
\hline
\end{tabular}

Yapılan puanlamanın ardından oluşturulan matrisler arasında aşağıdaki tutarlılık hesaplamaları yapılmıştır. Bu formüller genel tutarlılık formülleridir. Hesaplamalarda kullanılan Rastgele Tutarsızlık Endeksi oranı Çizelge 2 de yer almaktadır. Tutarlılık Endeksi (Consistency Index-Cl)

$C I=\frac{\lambda \max -\mathrm{n}}{\mathrm{n}-1}$

\section{Tutarlılık Oranı (Consistency Rate-CR)}

$C R=\frac{C I}{R I}$

\section{Öncelikler Vektörü (Priorities Vector)}

A: Karşılaştırma Matrisi (Comparison Martix)

p: Öncelikler Vektörü (Priorities Vector)

$\lambda$ : Maksimum Özdeğer (Maximal Eigenvalue)

$A * \vec{p}=\lambda * \vec{p}$

\section{Rastgele Tutarsızlık (Random Inconsistency-RI)}

Çizelge 2. Rastgele Tutarsızlık Çizelgesi

\begin{tabular}{lllllllllll}
\hline $\mathbf{n}$ & $\mathbf{1}$ & $\mathbf{2}$ & $\mathbf{3}$ & $\mathbf{4}$ & $\mathbf{5}$ & $\mathbf{6}$ & $\mathbf{7}$ & $\mathbf{8}$ & $\mathbf{9}$ & $\mathbf{1 0}$ \\
\hline $\mathrm{RI}$ & 0 & 0 & 0,58 & 0,90 & 1,12 & 1,24 & 1,32 & 1,41 & 1,45 & 1,49
\end{tabular}

Tüm sonuçlar incelendiğinde hesaplamaların tutarlı olup olmadığı hesabı, tutarlılık endeksi değerinin \%10'un altında (CR<0.1) kalması ile ilişkilidir (Dožić and Kalić 2014). Tüm sonuçlar bu çizelge, formüller ve sonuç değerleri üzerinden hesaplanmıştır ve tutarlılığı test edilmiştir. Karar verme yöntemi başka bir karar verme yöntemi olan İdeal Çözüme Benzerlikle Tercih Düzeni Tekniği (TOPSis) ile test edilip doğrulanmıştır.

\section{2 ideal Çözüme Benzerlikle Tercih Düzeni Tekniği (TOPSIS)}

Çok kriterli karar verme yöntemlerinden bir tanesi olan TOPSIS yöntemi 1981 yılında Hwang ve Yoon tarafından geliştirilmiştir (Wei 2010). Pozitif ideal çözüme en yakın mesafe ve negatif-ideal çözüme en uzak mesafe adımından yola çıkarak oluşturulmuştur (Monjezi et al. 2010). TOPSIS metodunun süreçleri 6 adımdan oluşmaktadır (Uygurtürk 2012). Illk adımda karar verme kriterlerinin belirlenerek karar matrislerinin oluşturulması gerekmektedir. Karar matrisinde seçenekler yukarıdan aşağıya bir hiyerarşide kaydedilir (Timor 2011).

TOPSIS yönteminin aşamaları aşağıda açıklanmıştır.

1. Amaçlar belirlenerek, karar matrisleri oluşturulur. Karar matrisinde satırlar alternatifleri, sütunlar ise kriterleri gösterir.

$K=\left[\begin{array}{ccc}a_{11} & \cdots & a_{1 n} \\ \cdots & \cdots & \cdots \\ a_{m 1} & \cdots & a_{m n}\end{array}\right]$

2. Kriterler ile alt kriterlerin karşılaştırılması ve üstünlüklerin belirlenmesi kapsamında karar matrisi oluşturulur (Supçiller ve Çapraz, 2011). Normalleştirme için, karar matrisindeki kriterlere ait değerlerin kareleri toplamının karekökü alınır.

$Z_{i j}=\frac{\mathrm{a}_{i j}}{\sqrt{\sum_{i=1}^{n} \mathrm{a}_{i j}^{2}}} \quad R=\left[\begin{array}{ccc}Z_{11} & \ldots & Z_{1 n} \\ \ldots & \ldots & \ldots \\ Z_{m 1} & \ldots & z_{m n}\end{array}\right]$

$(i=1, \ldots, n ; j=1, \ldots, k)$

3. Normalleştirilmiş karar matrisinde kriterlere verilen öncelikler aracılığıyla ağırlık değerleri hesaplanır. Standart karar matrisinin (V) bulunabilmesi için kriterlere ilişkin belirlenen kriter ağırlık değerleri $\left(w_{i}\right)$ ile çarpılarak bulunur.

$V=\left[\begin{array}{ccc}w_{11} & \ldots & w_{1 n} \\ \cdots & \cdots & \cdots \\ w_{m 1} & \ldots & w_{m n}\end{array}\right]$

4. Ağırlıklandırılmış matriste her bir sütunda en yüksek ve en düşük değerler belirlenerek $A+$ ve $A$ ideal noktaları tanımlanır. A+ en iyi performans 
değerlerini, A- ise en kötü değerleri temsil eder (Supçiller, Aliye Ayca Çapraz, Ozan).

Maksimum değerler,

$A^{+}=\left\{x_{1}^{+}, x_{2}^{+}, \ldots \ldots \ldots \ldots x_{k}^{+}\right\}$

Minimum değerler.

$A^{-}=\left\{x_{1}^{-}, x_{2}^{-}, \ldots \ldots \ldots \ldots x_{k}^{-}\right\}$

5. Maksimum ideal noktaya olan uzaklık

$\mathrm{S}_{i}^{+}=\sqrt{\sum_{j=1}^{k}\left(x_{i j}-x_{j}^{+}\right)^{2}}$

$(i=1, \ldots, n)$

Minimum ideal noktaya olan uzaklık

$\mathrm{S}_{i}^{-}=\sqrt{\sum_{j=1}^{k}\left(x_{i j}-x_{j}^{-}\right)^{2}}$

$(i=1, \ldots, n)$

6. Yakınlık katsayılarının hesaplanması sonucunda alternatiflerin puanı hesaplanır:

$C_{i}^{+}=\frac{\mathrm{s}_{i}^{-}}{\mathrm{s}_{i}^{+}+\mathrm{S}_{i}^{-}} \quad 1 \geq C_{i} \geq 0$

Elde edilen yakınlık katsayılarının $(C i+)$ değerlerine göre alternatifler sıralanır. Yakınlık katsayısı 0 ile 1 arasında değer alır. Yakınlık katsayısı en yüksek olan alternatifler arasında en iyi olarak kabul edilir.

\subsection{Grid Bazlı Haritalama}

Grid bazlı haritalama teknikleri çok yaygın olarak kullanılan bir haritalama tekniğidir. Türkiye'deki bina verilerinin eksik ve düzgün olmaması nedeni ile grid bazlı puanlama çalışılması amaçlanmıştır. Grid boyutu, mevcut veri kümesindeki zincir market lokasyonlarını baz alarak $500 \mathrm{~m} \times 500 \mathrm{~m}$ olarak seçilmiştir. Şekil 2 de İstanbul ili için hazırlanmış grid haritası gösterilmiştir. Boş olan alanlar verilerin o bölgede işleme girmeyeceğini göstermektedir.

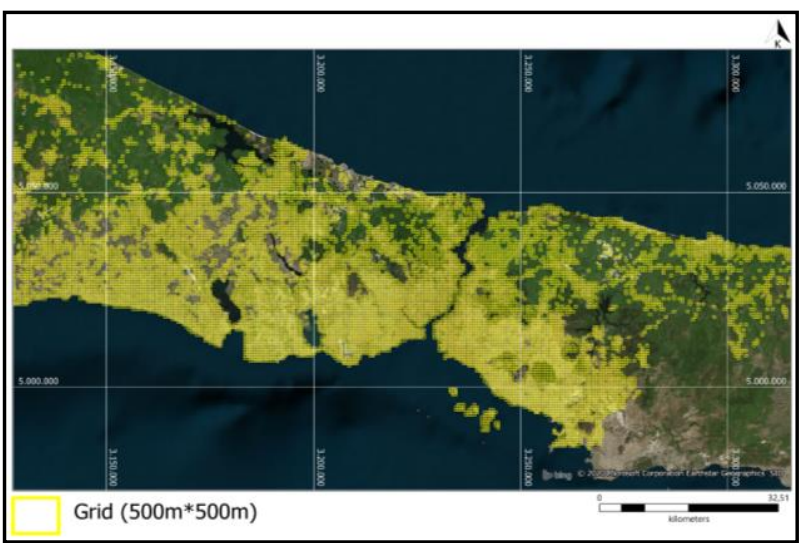

Şekil 2. İstanbul $500 \mathrm{~m} \times 500 \mathrm{~m}$ Grid Haritası

\section{Uygulama}

\section{1 Çalışma Alanı}

İstanbul nüfus, ekonomi ve kültürel bakımdan Türkiye ve Dünya'nın en önde gelen şehirlerinden biridir. Dünyada ekonomik büyüklükte 34., nüfus verilerine göre Avrupa'da 1., dünyada ise 6.'dır. 15,519,267 nüfusa sahip ilde 964 adet mahalle bulunmaktadır (Int Kyn. 2). Yapılan çalışmanın ana girdilerini nüfus ve işyeri yoğunluğunun oluşturması, küresel rekabet pazarının en aktif şekilde çalışılan şehri olması ve zincir market rekabetinin yoğun yaşanan bir bölge olması nedeni ile ístanbul ili çalışma alanı olarak seçilmiştir.

Çalışma kapsamında İstanbul ili baz alınarak veriler ve gridler çıkartılmıştır. Bu kapsamda toplamda 11,413 adet grid $(500 \mathrm{~m} \times 500 \mathrm{~m}$ ) mevcut olduğu tespit edilmiştir. Gridler coğrafi analizle CBS üzerinden hesaplanmış ve en küçük kesişime kadar alınmıştır. Grid verileri dışında POI verilerinden türetilen zincir market sayısı İstanbul ilinde 7,196 adettir. Şekil 3 'te Zincir Marketlerin İstanbul ili üzerindeki dağıımı harita kullanılarak gösterilmiştir.

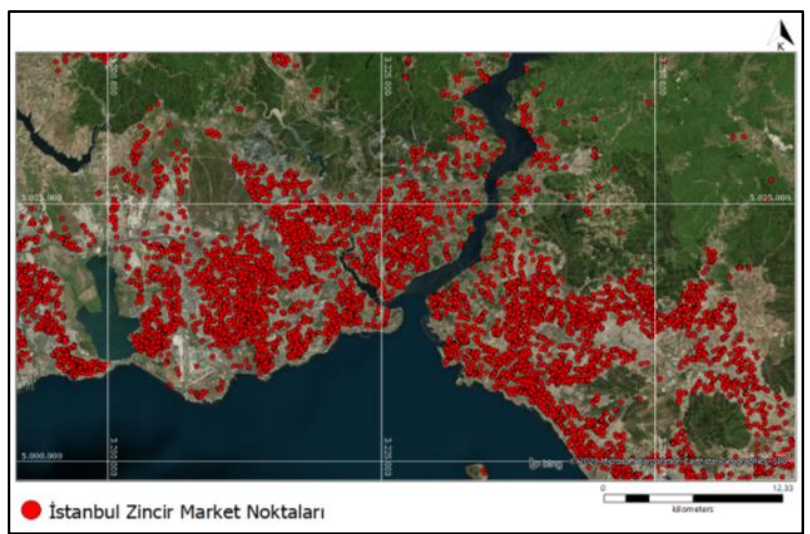

Şekil 3. İstanbul’ da Zincir Market Dağılımı Haritası

\subsection{Kriterler ve Veriler}


Yapılan literatür çalışması sonucunda verilerin bulunabilirliği de göz önünde bulundurularak aşağıdaki kriterler seçilmiştir. Seçilen kriterler için veri kaynakları ve çeşitleri Şekil 4 ve Çizelge 3'de detaylı olarak anlatılmıştır. Çalışma Türkiye'deki bina verilerinin sağlıksız olacağı göz önünde bulundurularak $500 \mathrm{~m} \times 500 \mathrm{~m}$ 'lik gridlere işlenerek hazırlanmış ve CBS üzerinde veri tabanı oluşturulmuş yazılıma aktarılmıştır.

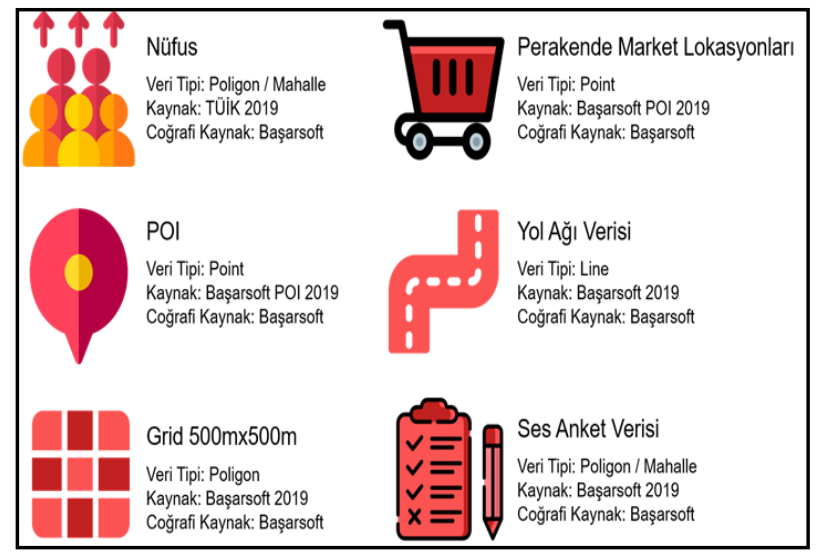

Şekil 4. Belirlenen Kriterler ve Veri Künyesi

Seçilen kriterlerin alt detayları nüfus, POI, Anket ve Yol Orta verileri başlıkları altında ayrıntıları ve açıklamaları Çizelge 3 de anlatılmıştır.

Çizelge 3. Veri Çizelgesi

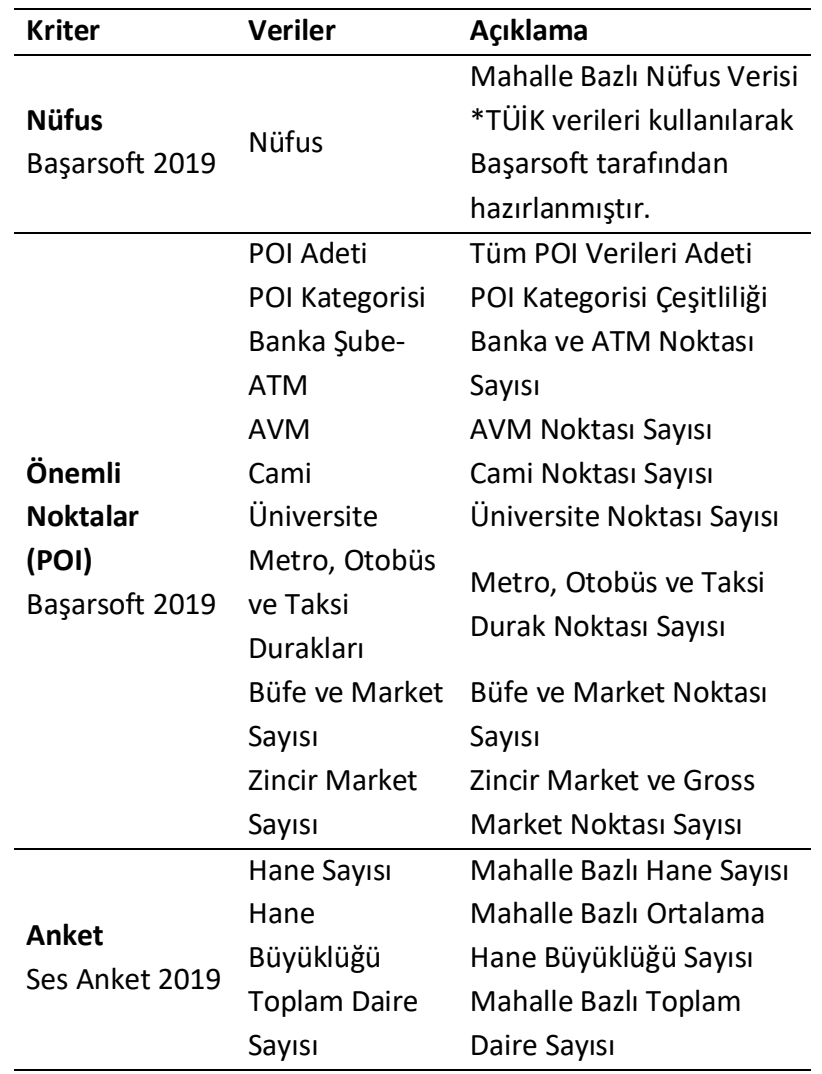

\begin{tabular}{lll}
\hline & Konut Sayısı & Mahalle Bazlı Konut Sayısı \\
& Yoğunluğu \\
(km² ye düşen) & Mahalle Bazlı Konut \\
İşyeri & Yoğunluğu Oranı \\
& Yoğunluğu & Mahalle Bazlı İşyeri \\
& Toplam Konut & Mahalle Bazlı Toplam \\
& Alanı & Konut Alanı \\
& Toplam & Mahalle Bazlı Toplam \\
& Harcama & Harcama Tutarı \\
& Ortalama Hane & Mahalle Bazlı Ortalama \\
& Harcama & Hane Harcama Tutarı \\
& Aylık Gelir & Mahalle Bazlı Ortalama \\
& İsyeri Sayısı & Mylık Gelir \\
& Aylık Harcama & Mahalle Bazlı İsyeri Sayısı \\
& Aylık Harcama Tutarı \\
\hline Yol Verisi & Yol Orta & Cadde, Sokak ve Bulvar \\
Başarsoft 2019 & Segment & Çizgi Verisi Segment \\
& Noktası & Kesişim Noktaları \\
\hline
\end{tabular}

Nüfus: 2019 yılında TÜiK kurumunun yayınladığı mahalle bazlı sözel nüfus verilerinin Başarsoft tarafından mahalle poligon verilerine işlenerek dönüştürülmüş halidir.

POI: Başarsoft tarafından sahadan ve anlaşmalı kurumlardan toplanan ve point halde tutulan önemli noktalar (Point of Interest-POI) veri kümesidir. Zincir Marketler ve diğer POI lokasyonları da bu veri kümesinden alınmış ve hesaba katılmıştır. Sahadan ve ilgili kurumlardan/firmalardan toplanan 65 farklı kategoride yaklaşı 3,5 milyon adet farklı kategorideki veriyi kapsamaktadır.

POI Kategorisi: POI verilerinin sınıflandırmasının kolaylığı bakımından alışveriş, eğitim, sağlık vb. kategorilerde tutulan POI verilerinin gruplandırılarak kategorize edilmesidir. Çalışmada grid içine düşen farklı kategorideki noktaların merkezi konumunu belirlemek için kullanılması amaçlanmıştır.

Yol Ağı Verisi: Başarsoft firması tarafından tüm Türkiye'de sahadan gezen araçlarla oluşturulan navigasyon tabanlı yol verisi kümesidir. Bu veri ile daha sonraki aşamalarda kapsam (Coverage) hesabı yapılabilmesi için segmentlere ait başlangıç bitiş noktaları üretilmiştir. Veri tüm cadde, sokak ve bulvarları içermektedir.

Ses Anket Verileri: Birçok kategorideki anket çalışma sonuçlarını, mahalle bazlı poligonlarda tutan verilerdir. 
Tüm veriler çalışmanın İstanbul ilinde yapılacak olması nedeni ile İstanbul iline indirgenmiştir. Çalışmada grid bazlı analiz yapılacağından veriler CBS ortamında işlenerek $500 \mathrm{~m} \times 500$ m'lik gridler haline dönüştürülmüştür. Bu işlem sırasında point veriler konumsal olarak yer aldığı grid içerisine veri olarak yazılmıştır. Ancak poligon tipinde mahalle bazlı olan nüfus ve anket verilerinin kapsamının geniş olması nedeni ile yol orta verilerinin segment başlangıç bitişleri kullanılarak, şehirleşmenin yoğun olduğu gridlerin daha yüksek puan alması için kapsam (Coverage) hesabı ile bu veriler mahallenin içerisinde yer alan yol orta verilerinin tamamının grid içerisinde yer alan yol orta segment başlangıç bitiş nokta adetlerine bölünmüş ve daha optimal şekilde gridlere dağıtılmıştır. Bu işlem tüm mahalle bazlı veriler (nüfus ve anket) için ayrı ayrı gerçekleştirilmiştir. Mahalle bazlı verilerin gridlerin içerisine yüzdesel olarak hesaplanması aşağıdaki Formül (1) de de anlatılmıştır.

\section{Kapsam Analizi (Coverage):}

m: Mahalleye işlenmiş Yol Segment Verisi

$y$ : Gride İslenmiş Yol Segment Verisi

p: Mahalle Bazındaki Poligon Veriler (Nüfus Ve Anket Verileri)

g: Gride Çevrilen Poligon Veriler

$g=\frac{y}{m} * p$

Sonuç olarak coverage hesabından geçen grid bazlı veriler ile aşağıdaki nüfus, hane sayısı, zincir market sayısı, aylık harcama, yol orta ve POI adeti haritaları üretilmiş ve Şekil 5'de gösterilmiştir.

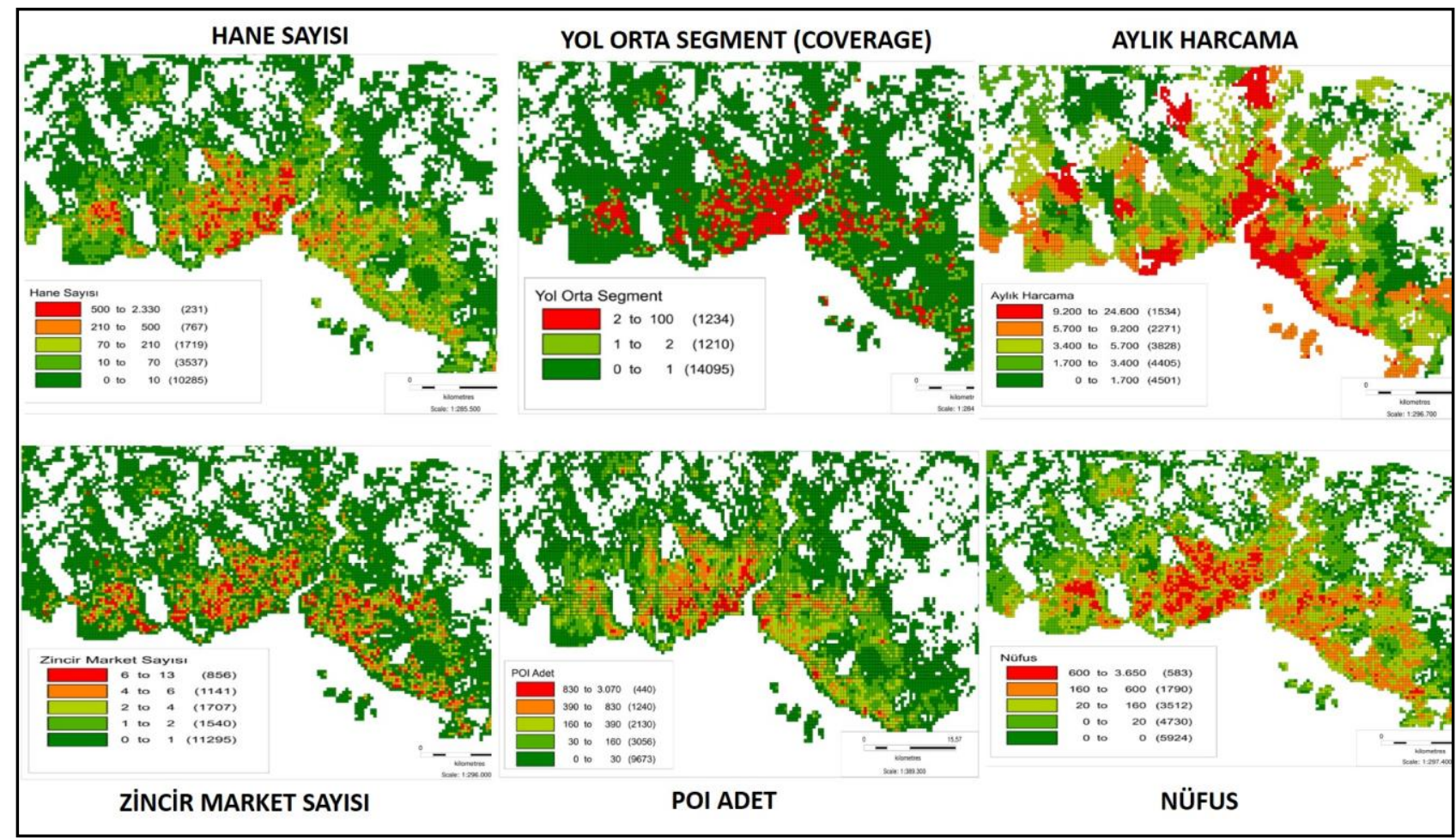

Şekil 5. Nüfus, Hane Sayısı, Zincir Market, POI Adeti, Yol Orta (Coverage), Aylık Harcama Grid Haritaları

\subsection{Web Yazılımı}

GeoKDS Web Uygulaması, veriler üzerinde coğrafi analizler ve raporlamalar yapabilen CBS tabanlı açık kaynak kod ile geliştirilmiş bir web analiz yazılımıdır. GeoKDS Uygulaması ile Başarsoft adres verisi kütüphanesi sayesinde adres arayabilmekte ve POI sorgulamaları gerçekleştirebilmektedir. AHP yöntemi baz alınarak tasarlanmış uygulama ile kullanıcı kendi özel kriterlerini ekleyebilmekte ve bu kriterlere ait verileri tayin edebilmektedir. Seçilen kriterlerin ağılıklandırılması da dinamik olarak kullanıcı tarafından yönetilebilmektedir. Yapılan analiz sonuçları harita üzerinde il, ilçe, mahalle, bölge ya da dinamik değiştirilebilen gridler halinde tematik harita şeklinde görüntülenebilmektedir (Int Kyn. 3). Tüm süreç boyunca işleme dahil edilen veriler, çıkan sonuçlar ve analizler uygulama tarafından raporlanabilmektedir. Yer seçimi ve karar 
destek aşamalarında birçok firma tarafından kullanılmakta ve uygulama müşterilerden alınan geri dönüşlere göre her geçen gün daha da geliştirilmektedir. Tüm bunlar düşünüldüğünde ortaya çıkan çalışmanın çoğu ihtiyacı karşılayabiliyor ve edinilmiş tecrübe sayesinde yazılımın geliştirilebilir olması, yazarlarımızın konu ile ilgili geçmiş deneyimlerinde uygulamaya hâkim olması ve seçilen birçok kritere ait verilerin uygulama içerisinde bulunuyor olması uygulamayı tercih sebebidir.

\section{4 Çalışma Adımları}

Çalışmadaki sonuçlara ulaşabilmek için uygulanan iş akışı Şekil $6^{\prime}$ da gösterilmiştir. İzlenilen bu iş akışı sayesinde potansiyeli en yüksek grid puanlaması yapılarak zincir marketler için en optimal yer seçimi haritasını ve bu harita üzerinden mevcut zincir marketlerin yerlerinin ne kadar uygun olduğuna dair karşılaştırma analizi sonuçları üretilmiştir.

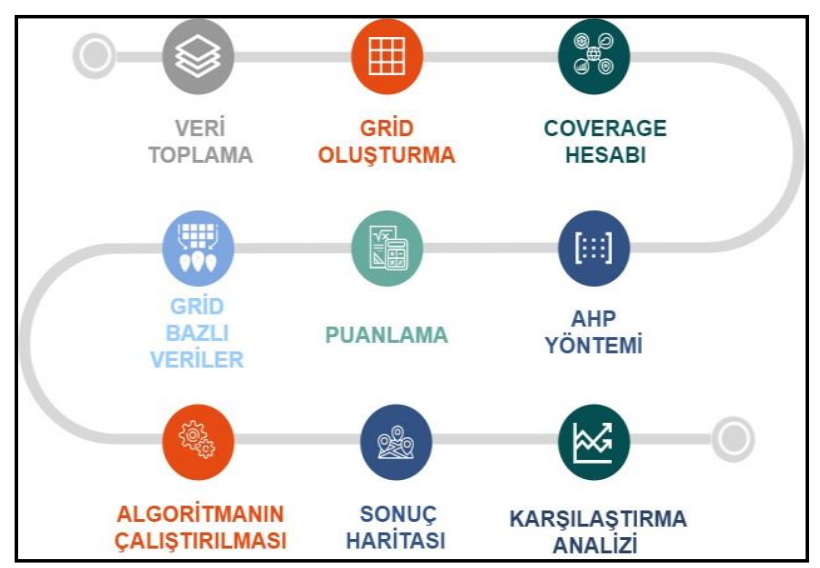

Şekil 6. Çalışma Adımları

\subsubsection{Veri Toplama}

GEOKDS yazılımında bulunan daha önce belirlenmiş olan Başarsoft ve TÜiK verileri üzerinden ilgili verilerin hesaba katılması için seçilmesi işlemidir. Bu aşamada veriler seçilmiş ve verilere ait alt detaylar incelenmiştir.

\subsubsection{Grid Oluşturma}

GEOKDS yazılımı üzerinde daha önce belirlenen grid boyutu ile dinamik olarak hesaplanan $500 \mathrm{~m} \times 500$ $\mathrm{m}$ gridler oluşturulmuş ve yer seçim hesabı için seçilmiştir. Çalışmanın bundan sonraki aşamasında gridlere veriler yazdırılacaktır.

\subsubsection{Kapsam Analizi (Coverage)}

Kapsam hesabının amacı, mahalle bazlı tutulan poligon verilerinin kendinden daha küçük olan 500 $\mathrm{m} \times 500 \mathrm{~m}$ gridler haline çevrilebilmesi için, Başarsoft yol orta segment verisinin gridlere ve mahalleye dağılımı yapılarak, mahallede tutulan verinin gride oranı ile grid verisi haline dönüşmesidir. Bu sayede yerleşim alanı olan yerler yol orta segment verisi ile belirlenerek nüfus ve anket verilerinin yeşil alandan çok yerleşim alanları bulunan gridlere yazı Iması sağlanmıştır. Diğer veriler point olarak tutulduğundan sadece gridler ile eşleştirilmesi sağlanmıştır.

Kullanılacak gridler $500 \mathrm{~m} \times 500 \mathrm{~m}$ boyutlarında tüm İstanbul ílini kapsayacak şekilde dışarı aktarılııştır. Her bir grid içerisinde kaç tane yol segment noktası olduğu hesaplanmıştır. Gridlerle mahalleler eşleştirilerek her bir gride düşen nokta sayısı mahalle bazında bulunmuştur. Bu hesaplamada tüm yol orta segment noktaları alınmamış, yerleşim olmayan yol orta segment noktaları hesaplamaya dahil edilmemiştir. Sadece yerleşim alanlarının hesaplanması amacıyla, yol orta segmentlerinin başlangıç ve bitiş noktalarına point atılarak gridlerle kesiştirilmiştir. Her bir grid ile kesişen mahalle sayısı hesaplanarak her mahalleye düşen toplam yol orta segment noktasının sayısı bulunmuştur. Coverage hesabı yapıldıktan sonra her bir veri hesaplanan coverage ile oranlanmıştır.

\subsubsection{Grid Bazlı Veriler}

Sonuç olarak tüm poligon ve point veriler gridler ile eşleştirilmiş ve GEOKDS yazılımı üzerinde oluşturulmuştur. Bu sayede daha sonraki aşamalarda bu veriler kullanılacaktır.

\subsubsection{Puanlama}

Her bir veri grubu daha önce literatür taramasında belirlenen kriterler çerçevesinde gruplandırılmıştır. Bu sayede hiyerarşik bir yapı oluşturulmuş ve her grubun kendi arasında karşılaştırma matrisi ile ağırlıklandırma puanları çıkartılmıştır. Her bir gurubun altında yer alan alt veriler için de aynı işlem yapılmış, bu sayede tüm kriterlerin ve alt kriterlerin ağırlıkları hesaplanmıştır. Çalışmada sezgisel olarak belirlenecek puanların dar ve orta gelirli müşterilere hitap eden bir market zincirinin yer seçim hedefleri doğrultusunda çıkartılması amaçlanmıştır. Bu amaç 
doğrultusunda literatürde en çok bahsi geçen kriterler çıkartılmış ve kriterler ampirik olarak tanımlanan ağırıklar ile birlikte aşağıdaki çizelgelerde ve Şekil 7 de gösterilmiştir. Çalışma kapsamında sezgisel ve tutarlı olarak verilen değerler ve grupların belirlenmesi için Başarsoft firmasında 7 yıldan fazla süredir çalışan ve sektör tecrübesine sahip 8 uzman tarafından ortak toplantı sonucunda verilmiştir. Uzmanlar yer seçimi ve parekende market sektöründe uzun yıllardır yer seçimi yazılım geliştirme, karar analizi, veri üretimi, anket çalışmaları ve coğrafi pazarlama analizleri konusunda çalışmaktadır. Uzmanlar mühendislik, iktisadi ve idari bilimler, işletme ve haritacılık sektörlerinde faaliyet göstermektedir. Tüm değerler tutarlık açısından kontrol edilmiş ve birbirileri ile uyumlu oranlar haline getirilmiştir. Ayrıca yazılımın kabiliyeti sebebiyle değerler başka uzmanların sezgisel veya bilimsel çalışmaları sonucunda kolayca değiştirilerek yeni sonuçlar üretmeye açıktır.

Tüm kriterler ve alt kriterler için karşılaştırma matrisleri Tutarlılık Indeksi (CI) ve Tutarlılık Oranı (CR) puanları hesaplanarak bu değerlerin \%10 altında kalması sağlanmıştır. Buradaki amaç değerlerin tutarsızlığının önüne geçmek ve bir hata var ise matrisi yenilemektir. Sonuç olarak oluşturulan matrisler, ağılıklandırma puanları ve tutarlılık değerleri aşağıdaki çizelgelerde belirtilmiştir. İkili karşılaştırma matrisi olan Düşük Rekabet ve Ulaşım Kolaylığı alt kriterleri için $\mathrm{Cl}$ ve $\mathrm{CR}$ değerleri hesaplanmamıştır. Çizelge 4'te kriter karşılaştırma matrisi ve tutarlılık oranları gösterilmiştir. Çizelge 5, Çizelge 6, Çizelge 7, Çizelge 8, Çizelge 9 ve Çizelge $10^{\prime}$ da ise Ulaşım Kolaylı̆̆ı, Talep Kapasitesi, Harcama Kapasitesi, Merkezi Konum, Düşük Rekabet ve Diğer Önemli Noktalara Yakınlık kriterlerinin alt kriterlerinde yer alan alt kriterlerin karşılaştırma matrisleri ve tutarlılık oranları gösterilmiştir.

Çizelge 4. Kriter Karşılaştırma Matrisi

*Ulaşım Kolaylığı: UK, Talep Kapasitesi: TK, Harcama Kapasitesi: HK, Merkezi Konum: MK, Düşük Rekabet: DR, Diğer Önemli Noktalara Yakınlık: DNY

\begin{tabular}{cccccccc}
\hline Kriterler & UK & TK & HK & MK & DR & DNY & Ağırlık \\
\hline UK & 1 & $1 / 9$ & $1 / 4$ & $1 / 4$ & $1 / 9$ & $1 / 4$ & $2,68 \%$ \\
\hline
\end{tabular}

\begin{tabular}{cccccccc}
\hline TK & 9 & 1 & 3 & 4 & 3 & 5 & $40,06 \%$ \\
\hline HK & 4 & $1 / 3$ & 1 & $1 / 3$ & $1 / 4$ & 3 & $9,79 \%$ \\
\hline MK & 4 & $1 / 4$ & 3 & 1 & $1 / 4$ & 2 & $12,63 \%$ \\
\hline DR & 9 & $1 / 3$ & 4 & 4 & 1 & 5 & $28,66 \%$ \\
\hline ONY & 4 & $1 / 5$ & $1 / 3$ & $1 / 2$ & $1 / 5$ & 1 & $6,18 \%$ \\
\hline & & & Cl: $10 \%$ \\
CR: $8 \%$ & & &
\end{tabular}

Çizelge 5. Talep Kapasitesi Alt Kriter Karşılaştırma Matrisi *Nüfus: N, Hane Sayısı: HS, Konut Sayısı: KS, Konut Yoğunluğu: KY, Hane Büyüklüğü: HB, Toplam Daire Sayısı: TDS, Toplam Konut Alanı: TKA

\begin{tabular}{lcccccccc}
\hline $\begin{array}{c}\text { Talep } \\
\text { Kapasitesi }\end{array}$ & N & HS & KS & KY & HB & TDS & TKA & Ağırlık \\
\hline N & 1 & 5 & 6 & 7 & 4 & 5 & 7 & $43,21 \%$ \\
\hline HS & $1 / 5$ & 1 & 3 & 4 & 1 & 5 & 5 & $17,66 \%$ \\
\hline KS & $1 / 6$ & $1 / 3$ & 1 & 2 & $1 / 3$ & $1 / 3$ & 2 & $5,43 \%$ \\
\hline KY & $1 / 7$ & $1 / 4$ & $1 / 2$ & 1 & $1 / 4$ & $1 / 3$ & 1 & $3,63 \%$ \\
\hline HB & $1 / 4$ & 1 & 3 & 4 & 1 & 5 & 6 & $18,37 \%$ \\
\hline TDS & $1 / 5$ & $1 / 5$ & 3 & 3 & $1 / 5$ & 1 & 4 & $8,49 \%$ \\
\hline TKA & $1 / 7$ & $1 / 5$ & $1 / 2$ & 1 & $1 / 6$ & $1 / 4$ & 1 & $3,22 \%$ \\
\hline & & & Cl: $11 \%$ & & & \\
& & & &
\end{tabular}

Çizelge 6. Merkezi Konum Alt Kriter Karşılaştırma Matrisi

\begin{tabular}{lccccc}
\hline $\begin{array}{l}\text { Merkezi } \\
\text { Konum }\end{array}$ & $\begin{array}{c}\text { Iş̧ Yeri } \\
\text { Sayısı }\end{array}$ & $\begin{array}{c}\text { İş Yeri } \\
\text { Yoğunluğu }\end{array}$ & $\begin{array}{c}\text { POI } \\
\text { Adeti }\end{array}$ & $\begin{array}{c}\text { POI } \\
\text { Kategorisi }\end{array}$ & Ağırlık \\
\hline $\begin{array}{l}\text { İ̧̧ Yeri } \\
\text { Sayısı }\end{array}$ & 1 & 7 & 2 & $1 / 3$ & $25,34 \%$ \\
\hline $\begin{array}{l}\text { Iş Yeri } \\
\text { Yoğunluğu }\end{array}$ & $1 / 7$ & 1 & $1 / 5$ & $1 / 8$ & $4,33 \%$ \\
\hline POI Adeti & $1 / 2$ & 5 & 1 & $1 / 4$ & $15,35 \%$ \\
\hline $\begin{array}{l}\text { POI } \\
\text { Kategorisi }\end{array}$ & 3 & 8 & 4 & 1 & $54,97 \%$ \\
\hline \multicolumn{5}{c}{$\begin{array}{l}\text { Cl: } 4 \% \\
\text { CR: } 5 \%\end{array}$} \\
\end{tabular}

Çizelge 7. Harcama Kapasitesi Alt Kriter Karşılaştırma Matrisi

\begin{tabular}{lccccc}
\hline $\begin{array}{l}\text { Harcama } \\
\text { Kapasitesi }\end{array}$ & $\begin{array}{c}\text { Aylık } \\
\text { Gelir }\end{array}$ & $\begin{array}{l}\text { Aylık } \\
\text { Harcama }\end{array}$ & $\begin{array}{c}\text { Ortalama } \\
\text { Harcama }\end{array}$ & $\begin{array}{l}\text { Toplam } \\
\text { Harcama }\end{array}$ & Ağırlık \\
\hline Aylık Gelir & 1 & $1 / 4$ & $1 / 3$ & $1 / 5$ & $6,93 \%$ \\
\hline $\begin{array}{l}\text { Aylık } \\
\text { Harcama }\end{array}$ & 4 & 1 & 4 & $1 / 2$ & $32,51 \%$ \\
\hline $\begin{array}{l}\text { Ortalama } \\
\text { Harcama }\end{array}$ & 3 & $1 / 4$ & 1 & $1 / 4$ & $12,88 \%$ \\
\hline $\begin{array}{l}\text { Toplam } \\
\text { Harcama }\end{array}$ & 5 & 2 & 4 & 1 & $47,68 \%$ \\
\hline & & $\begin{array}{l}\text { Cl: } 6 \% \\
\text { CR: } 6 \%\end{array}$
\end{tabular}


Çizelge 8. Diğer Önemli Noktalara Yakınlık Alt Kriter Karşılaştırma Matrisi

\begin{tabular}{|c|c|c|c|c|c|}
\hline $\begin{array}{l}\text { Diğer } \\
\text { Önemli } \\
\text { Noktalara } \\
\text { Yakınlık }\end{array}$ & $\begin{array}{c}\text { Banka } \\
\text { ATM }\end{array}$ & AVM & Cami & Üniversite & Ağırlık \\
\hline Banka ATM & 1 & $1 / 3$ & 5 & 2 & $24,67 \%$ \\
\hline AVM Azlığı & 3 & 1 & 6 & 4 & $54,17 \%$ \\
\hline Cami & $1 / 5$ & $1 / 6$ & 1 & $1 / 4$ & $5,68 \%$ \\
\hline Üniversite & $1 / 2$ & $1 / 4$ & 4 & 1 & $15,48 \%$ \\
\hline
\end{tabular}

Çizelge 9. Ulaşım Kolaylığı Alt Kriter Karşılaştırma Matrisi

\begin{tabular}{lccc}
\hline Ulaşım Kolaylı̆ı & $\begin{array}{l}\text { Yol Orta } \\
\text { Segment }\end{array}$ & $\begin{array}{l}\text { Metro Taksi } \\
\text { Otobüs } \\
\text { Durakları }\end{array}$ & Ağırlık \\
\hline Yol Orta Segment & 1 & 7 & $88 \%$ \\
\hline $\begin{array}{l}\text { Metro Taksi } \\
\text { Otobüs Durakları }\end{array}$ & $1 / 7$ & 1 & $12 \%$ \\
\hline
\end{tabular}

Çizelge 10. Düşük Rekabet Alt Kriter Karşılaştırma Matrisi

\begin{tabular}{lccc}
\hline Düşük Rekabet & $\begin{array}{l}\text { Zincir Market } \\
\text { Sayısı Azlığı }\end{array}$ & $\begin{array}{l}\text { Büfe ve } \\
\text { Market }\end{array}$ & Ağırlık \\
\hline $\begin{array}{l}\text { Zincir Market } \\
\text { Sayısı Azlığı }\end{array}$ & 1 & 8 & $89 \%$ \\
\hline $\begin{array}{l}\text { Büfe ve } \\
\text { Market Azlığı }\end{array}$ & $1 / 8$ & 1 & $11 \%$ \\
\hline
\end{tabular}

Hesaplanan matrisler sayesinde ortaya çıkan ağırlıklandırma puanları ve genel hiyerarşi Şekil 7'de anlatılmıştır. Buradaki puanlar hiyerarşik yapıda çıkartılan kriter puanları üzerinden alt kriterlerin oranları ile hesaplanarak oluşturulmuş ve her bir kriterin alt kriterler üzerinden etkilenerek oluşturulmuş hiyerarşik yapısı şekil 7'de gösterilmiştir. Kriterler üzerinden alt kriterlerin son değerlerinin nasıl çıkarıldığı aşağıdaki formülde açıklanmıştır. Kriter puanı, talep kapasitesi, harcama kapasitesi, ulaşım kolaylığı, düşük rekabet, merkezi konum ve diğer önemli noktalara yakınlık değerleri üzerinden Çizelge 4'ten hesaplanmıştır. Alt kriter puanları için, Çizelge 5, Çizelge 6, Çizelge 7, Çizelge 8, Çizelge 9 ve Çizelge 10 'daki matrislerden elde edilmiş ağırlık değerleri hesaba katılmıştır. Her bir alt kriter bulunduğu kriter üzerinden hesaba katılmıştır. Matrislerle hesaplanan kriter ağırlık değerleri AHP ve TOPSIS yöntemi üzerinden hesaplamalara dahil edilmiş ve sonuçlar kıyaslanmıştır.

Kriter Puanı: $p$
Alt Kriter Puanı: a

Değerlendirmeye alınacak Son Alt Kriter Puanı: d

$d=p * a$

Yapılan puanlamalar sayesinde en fazla önemli olan kriter Talep Kapasitesi ve Düşük Rekabet olarak belirlenmiştir. Alt kriterler incelendiğinde ise Düşük Zincir Market Sayısı \%25,51 ve Nüfus \%17,31 ile en önemli alt kriterler olarak gözükmektedir. Daha sonraki aşamada yapılan sonuç puanının en fazla bu kriter ve alt kriterlerden hesaplanacağı öngörülmektedir.

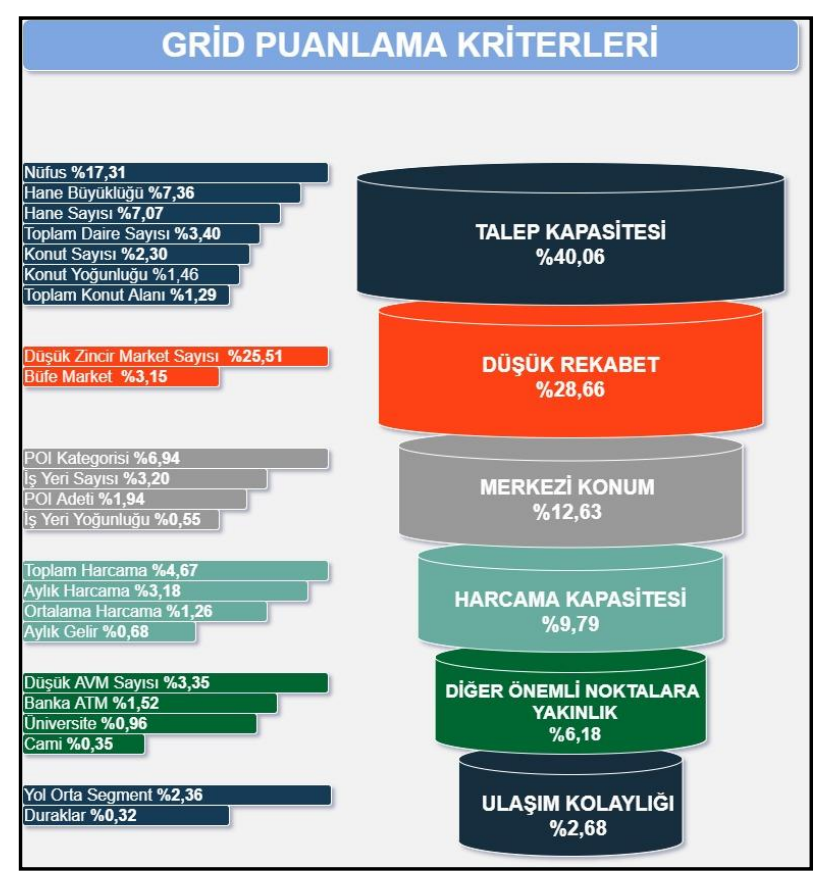

Şekil 7. AHP Yöntemi ile Grid Ağırlıklandırma Kriterleri

\subsubsection{AHP Yöntemi}

AHP yöntemi kullanılarak kriter ve alt kriterlerin ağırlıklandırma puanları ve daha önceki gride işlenmiş verilerin kullanıla bilinmesi adına verilerin normalizasyon işlemi ile " 0 ve 1 " arasına alınma işlemi gerçekleştirilmiştir.

\section{Normalizasyon}

Normalizasyon işlemi için aşağıdaki formül kullanılmıştır.

$v^{\prime}$ : Normalize Edilmiş Değer

$v^{\prime}=\frac{v-v_{\min }}{v_{\max }-v_{\min }}$

Oluşan değerlerde düşük rekabeti hesaplayabilmek adına, gridlere yazdırılan verilerden Zincir Market 
Sayısı, Büfe ve Market Sayısı ve AVM sayıları için normalize edilen değerler 1 'den çıkartılarak olumsuz etkileri ortadan kaldırılmıştır. Bu üç veri için olumsuz etkilerini ortadan kaldıran formül aşağıda yer almaktadır. Bu sayede seçim yapılan grid için fazla sayıda Zincir Market, Büfe ve Market ve AVM bulunması durumunda seçimin ters yönde etkilenmesi amaçlanmıştır. Kısacası fazla rekabet olan yerleri seçmemek için bu yöntem kullanılmıştır. v": Olumsuz Etkileri Kaldırılmış Normalize Edilmiş Değer

$v^{\prime \prime}=1-\frac{v-v_{\min }}{v_{\max }-v_{\min }}$

\section{Toplam Grid Puanı (Total Grid Score)}

Her bir grid için gridlerdeki normalize edilmiş değerler AHP yöntemi ile hesaplanan kriter ve alt kriter ağılıklandırma puanları ile çarpılarak sonuç grid puanı hesaplanmıştır. Puanlamalar sezgisel olarak tutarsızlık engellenerek verilmiştir. Ancak GEOKDS yazılımının dinamikliği sayesinde başka veriler, kriterler ve verilen puanlar sayesinde farklı sonuçlar elde edilebilir. Toplam grid puanı hesaplanırken aşağıdaki formül kullanılmıştır.

A: Her Bir Alt Kriter Için Normalize Edilmiş Değer p: HP ile Hesaplanmış Her Bir Alt Kriter için Ağırlıklandırma Puanı

t: Total Grid Score

k: Alt Kriter Sayısı

$t=\sum_{k=0}^{n} a * p$

\subsubsection{Algoritmanın Çalıştırılması}

Çalışma tüm normalize edilmiş veriler ve sonuç toplam grid puanı hesaplama formülü üzerinden GEOKDS yazılımı sayesinde hesaplanmıştır. Tüm gridlere ait toplam grid puanı hesaplanmış ve sonraki aşamada haritada görselleştirmek adına GEOKDS yazılımı üzerinden gridlere yazdırılmıştır.

\subsubsection{Sonuç Haritası}

Çıkan sonuçlar incelendiğinde sonuçları daha anlamlı sınıflandırabilmek adına normalizasyon işlemi ile değerler 0 ile 1 arasına alınmıştır. Yapılan sınıflandırma ile $0-0.40$ arası düşük potansiyelli, $0.40-0.50$ arası orta potansiyelli ve $0.50-1$ arası ise yüksek potansiyelli şekilde sınıflandırılmıştır. İstanbul genelinde 75 adet yüksek potansiyelli, 446 adet orta potansiyelli ve 10,892 adet düşük potansiyelli grid tespit edilmiştir. Sonuç haritaları Şekil 8 ve Şekil 9'da gösterilmiştir. Çıkarılan sonuç incelendiğinde gridlerin Üsküdar, Şişli, Bakırköy, Bayrampaşa, Beşiktaş, Beyoğlu, Esenler, Esenyurt, Fatih, Güngören, Gaziosmanpaşa, Kağıthane, Kadıköy, Zeytinburnu ilçelerinde bulunan 87 adet mahallenin yüksek potansiyelli gridler ile kesişmekte olduğu tespit edilmiştir.

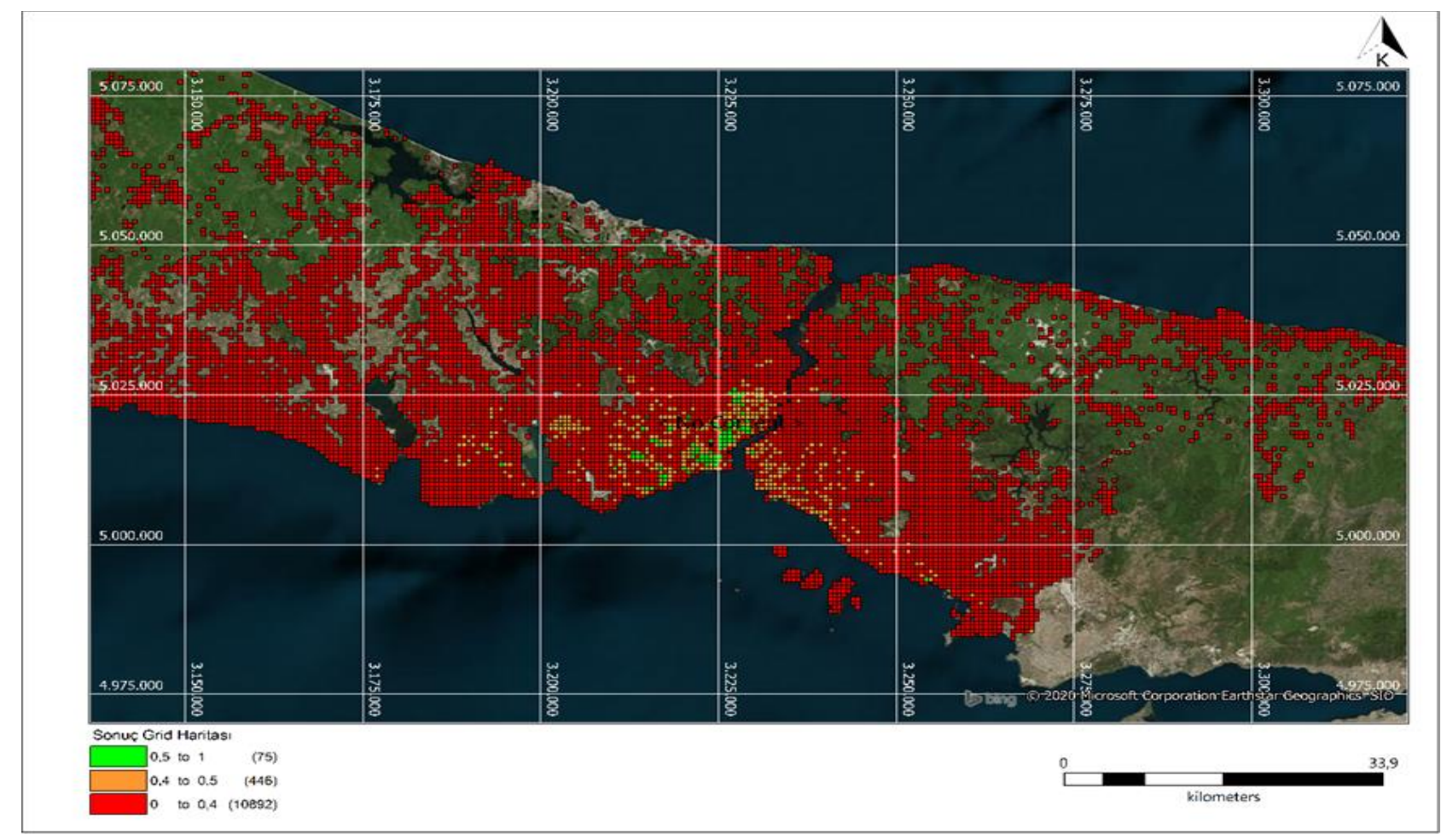

Şekil 8. Sonuç Grid Puanlama Haritası 


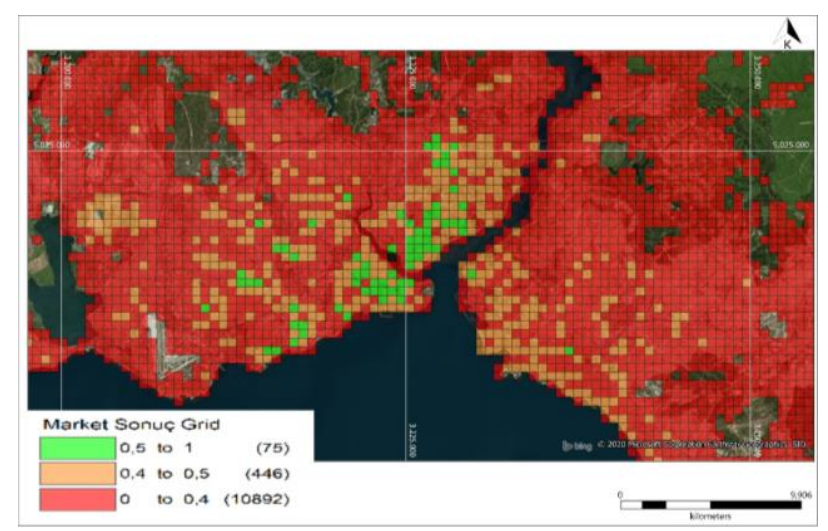

Şekil 9. Yüksek Potansiyelli Gridlere Yakınlaşmış Sonuç Grid Puanlama Haritası

\subsubsection{Karşılaştırma Analizi}

Gerçek market verileri ile çıkan sonuçların karşılaştırılması sonucunda elde edilen haritalar Şekil 10 ve Şekil 11'de gösterilmiştir. Bu sayede gerçek zincir market lokasyonları ile çıkan sonuçlar karşılaştırılarak gerçek zincir market lokasyonlarının çıkan sonuç üzerinde yüksek, orta ve düşük potansiyelli olarak sınıflandırılması sağlanmıştır. Yapılan çalışma sonucunda yüksek potansiyelli alanda 218 adet zincir market vardır.

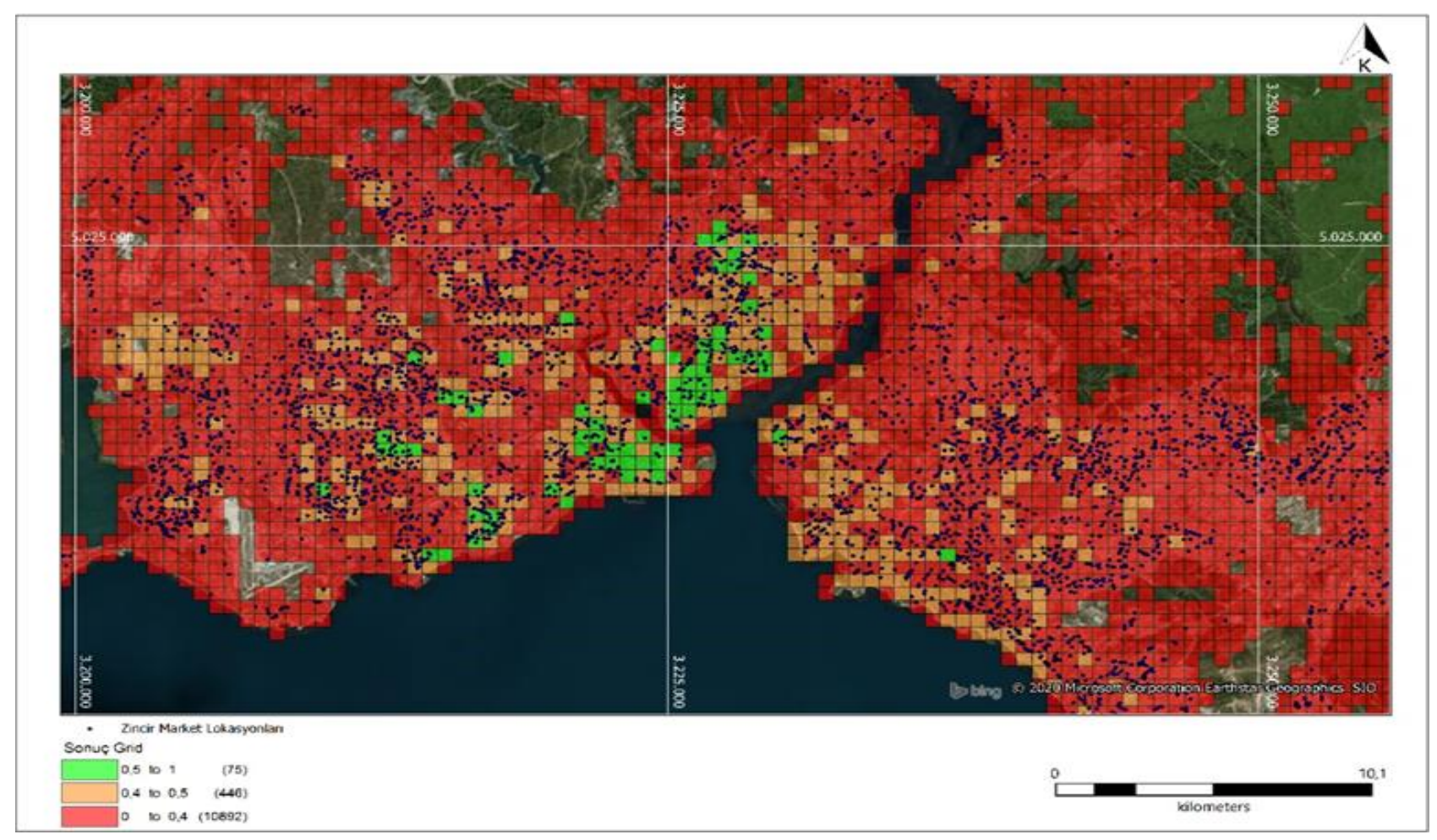

Şekil 10. Sonuç Grid Haritaları ile Mevcut Zincir Market Lokasyonlarının Kesişimi

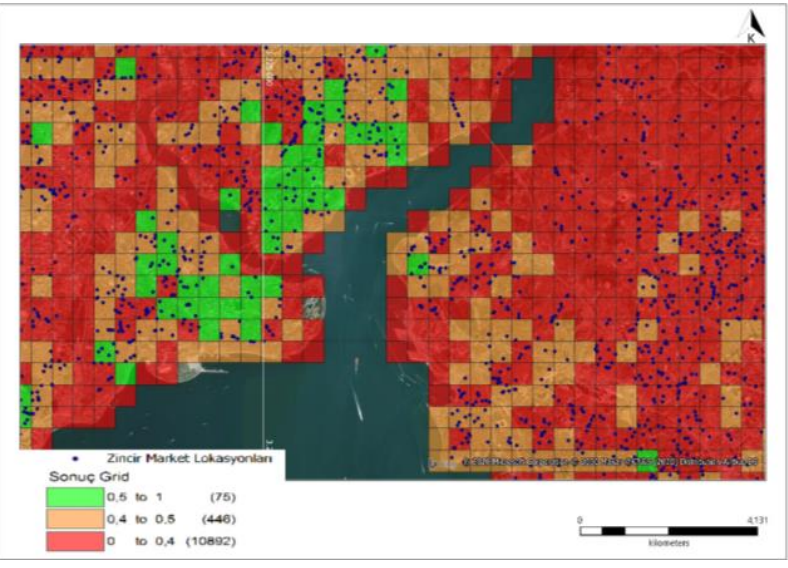

Şekil 11. Yüksek Potansiyelli Gridlerde Yer Alan Mevcut Zincir Market Lokasyon Hariç 


\section{TOPSIS Yöntemi}

Karşılaştırma matrisleri sonucu hesaplanan kriter ağırlık değerleri TOPSIS metodu üzerinden tekrar analize sokulmuş ve çıkan sonuçlar Şekil 12 ve Şekil 13 ' de gösterilmiştir. TOPSIS metodu ile hesaplanan sonuçlarda AHP yöntemi ile hesaplanan haritalar ve analiz sonuçlarına benzer sonuçlar ortaya konulmuştur. TOPSIS yöntemi ile çıkan analiz sonuçlarında $0,5^{\prime}$ in üstünde 55 adet grid bulunmuştur. Sonuçların ardından AHP yöntemi ile hesaplanmış haritaların harita gösterimi ve aralıkların uyması adına TOPSIS sonucunda çıkan değerler normalize edilmiştir. Bu sayede tüm sonuç değerler 0 ile 1 aralığına alınmış, AHP sonuçları ile uyumu sağlanmıştır.

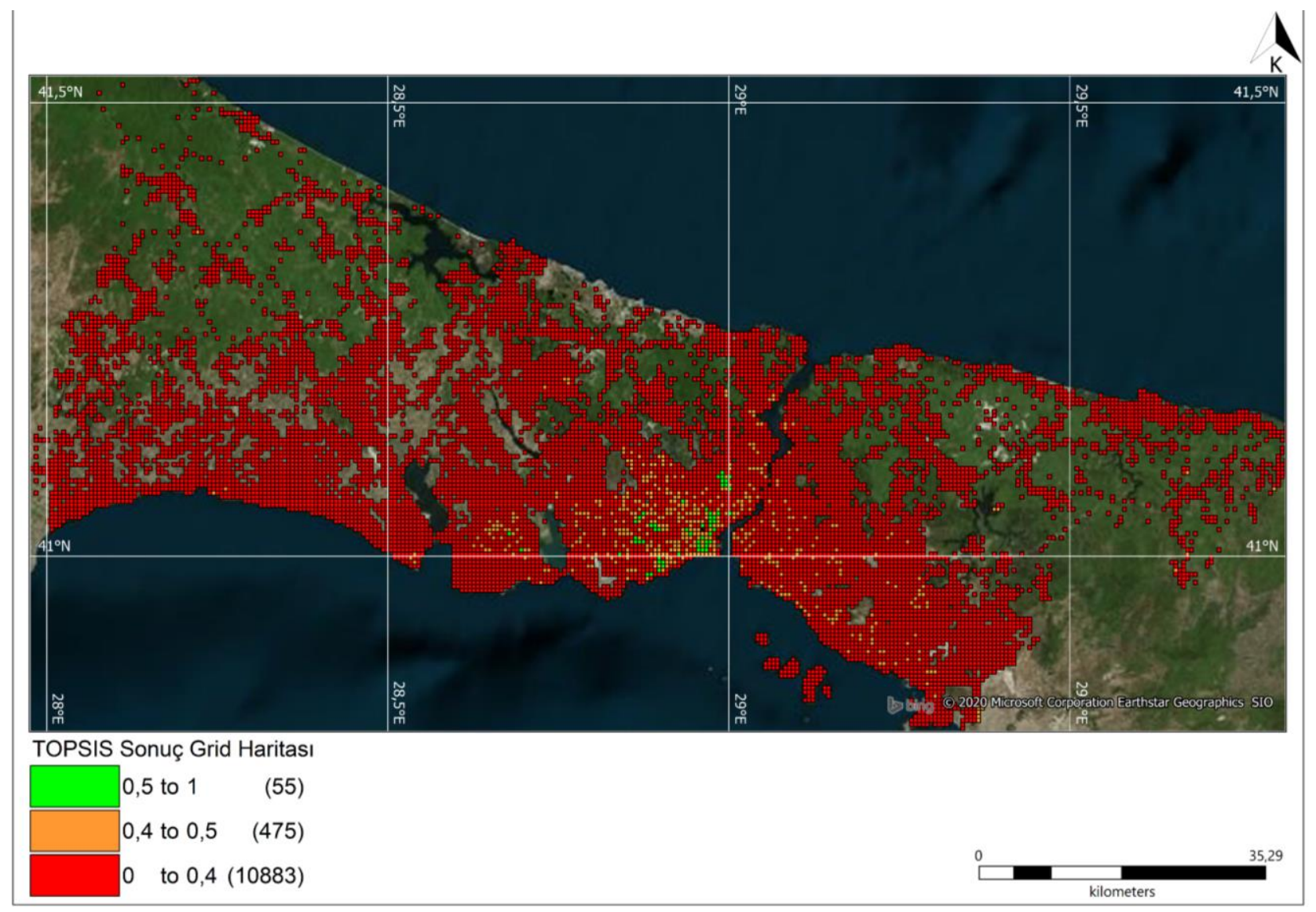

Şekil 12. TOPSIS Sonuç Grid Puanlama Haritası

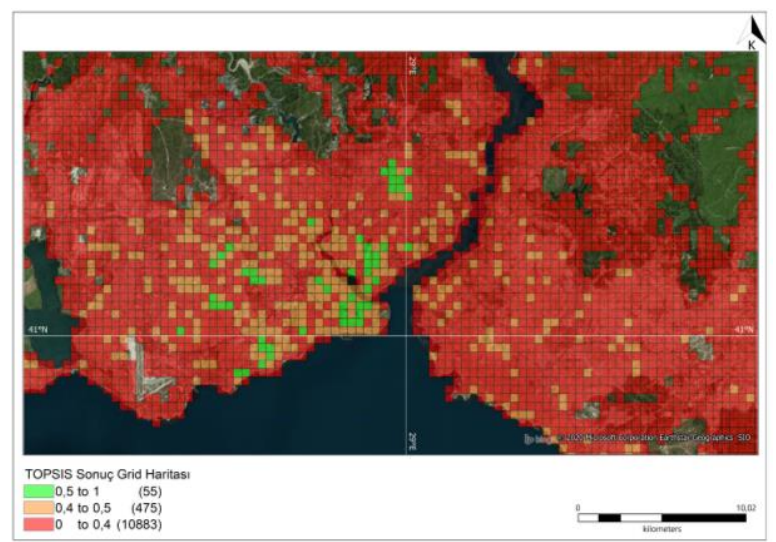

Şekil 13. Yüksek Potansiyelli Gridlere Yakınlaşmış TOPSIS Sonuç Grid Puanlama Haritası

\section{Tartışma ve Sonuç}

Oldukça önemli olan perakende market yer seçimi için mevcut tüm etkenlerin değerlendirilmesi gerekmektedir. Optimal yer seçimi için CBS yöntemlerinin kullanılması henüz yeterince yaygın olmamakla birlikte, her geçen gün daha fazla kurumsal firma CBS tabanlı karar verme mekanizması oluşturmaktadır. CBS sayesinde, coğrafi ve coğrafi olmayan birçok veri birlikte analiz edilebilmekte ve optimal karar verme süreci oluşturulabilmektedir. Bu çalışmada, çok fazla etken birlikte analiz edilmiş ve ülkemizde bu alanda yapılan en kapsamlı analiz ortaya konulmuştur. Harcama kapasitesi, ulaşım, düşük rekabet, merkezi konum ve diğer önemli noktalara yakınlık kriterleri ve bu kriterlerin alt kriterleri olan Nüfus, POI Adeti, 
POI Kategorisi, Banka Şube-ATM, AVM, Cami, Üniversite, Metro, Otobüs ve Taksi Durakları, Büfe ve Market Sayısı, Zincir Market Sayısı, Hane Sayısı, Hane Büyüklüğü, Toplam Daire Sayısı, Konut Sayısı, Konut Yoğunluğu (km2 ye düşen), İşyeri Yoğunluğu, Toplam Konut Alanı, Toplam Harcama, Ortalama Hane Harcama, Aylık Gelir, İşyeri Sayısı, Aylık Harcama ve Yol Orta Segmentine uzaklık çalışmada kullanılan veri setleridir. Oluşturulan ağırlık matrisleri özdeğer (eigenvalue) ve özvektörler (eigenvector) analizi ile ayrıştırılmış ve her bir grid için yukarıdaki tüm veriler dikkate alınarak grid puanı AHP ve TOPSIS yöntemleriyle ayrı ayrı hesaplanmıştır. Hesaplama sonucunda grid puanı ile değerler yüksek potansiyelli, orta potansiyelli ve düşük potansiyelli gridler olarak sınıflandırılmıştır. Çıkarılan grid sonuç haritaları ile mevcut zincir market noktalarının çakıştırıması ile elde edilen haritalar paylaşılmıştır. AHP ve TOPSIS yöntemi ile hesaplanan sonuçlara göre Çizelge $11^{\prime}$ de gösterilen yüksek potansiyel, orta potansiyel ve düşük potansiyel olan gridlerin adetleri belirtilmiştir. Çizelge $12^{\prime}$ de ise sonuç gridleri ile kesiştirilen mevcut zincir market lokasyon sayıları yer almaktadır.

Çizelge 11. Sonuç Puanı Hesaplanmış Grid Potansiyel Çizelgesi

\begin{tabular}{lcccc}
\hline Grid Açıklama & $\begin{array}{c}\text { AHP } \\
\text { Yöntemi } \\
\text { Adet }\end{array}$ & $\begin{array}{c}\text { TOPSIS } \\
\text { Yöntemi } \\
\text { Adet }\end{array}$ & Aralık & $\begin{array}{c}\text { Harita } \\
\text { Gösterim } \\
\text { Rengi }\end{array}$ \\
\hline $\begin{array}{l}\text { Yüksek } \\
\text { Potansiyelli } \\
\text { Grid }\end{array}$ & 75 & 55 & $0,5-1$ \\
\hline $\begin{array}{l}\text { Orta } \\
\text { Potansiyelli }\end{array}$ & 446 & 475 & $0,4-0,5$ \\
Grid & & & \\
\hline $\begin{array}{l}\text { Düşük } \\
\text { Potansiyelli } \\
\text { Grid }\end{array}$ & 10.892 & 10.883 & $0-0,4$ \\
\hline
\end{tabular}

Çizelge 12. Sonuç Grid Puanı Üzerinden Mevcut Zincir Market Lokasyonları Karşılaştırma Analizi Sonuç Çizelgesi

\begin{tabular}{lccc}
\hline $\begin{array}{l}\text { Mevcutta Bulunan } \\
\text { Zincir Market }\end{array}$ & $\begin{array}{c}\text { AHP } \\
\text { Yöntemi } \\
\text { Adet }\end{array}$ & $\begin{array}{c}\text { TOPSIS } \\
\text { Yöntemi } \\
\text { Adet }\end{array}$ & $\begin{array}{c}\text { Harita } \\
\text { Gösterim } \\
\text { Rengi }\end{array}$ \\
\hline $\begin{array}{l}\text { Yüksek Potansiyelli } \\
\text { Gridle Kesişen Zincir } \\
\text { Marketler }\end{array}$ & 218 & 175 & \\
\hline
\end{tabular}

\begin{tabular}{lll}
\hline $\begin{array}{l}\text { Orta Potansiyelli } \\
\text { Gridle Kesişen Zincir }\end{array}$ & 768 & 457 \\
Marketler & & \\
\hline $\begin{array}{l}\text { Düşük Potansiyelli } \\
\text { Gridle Kesişen Zincir }\end{array}$ & 6213 & 6567 \\
Marketler & & \\
\hline
\end{tabular}

Çalışma sonucunda AHP yöntemi ile hesaplanan sonuç grid puanlama verisinde örnek olarak Çizelge 13 'deki 10 adet en yüksek potansiyelli grid için grid puanı, nüfus ve rekabet halinde olduğu zincir market sayısı paylaşılmıştır.

Çizelge 13. AHP Yöntemi ile Çıkarılan Illk 10 Verinin Nüfus ve Zincir Market Sayıları

\begin{tabular}{lccc}
\hline Grid No & $\begin{array}{c}\text { Yaklaşık } \\
\text { Nüfus } \\
\text { Adeti }\end{array}$ & $\begin{array}{c}\text { Grid İçerisinde } \\
\text { Yer Alan Zincir } \\
\text { Market Sayısı }\end{array}$ & $\begin{array}{c}\text { Toplam } \\
\text { Sonuç Grid } \\
\text { Puanı }\end{array}$ \\
\hline Grid 1 & 5367,98 & 2 & 1 \\
\hline Grid 2 & 1209,19 & 0 & 0,84 \\
\hline Grid 3 & 3529,24 & 3 & 0,80 \\
\hline Grid 4 & 3051,69 & 1 & 0,79 \\
\hline Grid 5 & 1370,32 & 1 & 0,71 \\
\hline Grid 6 & 4190,1 & 4 & 0,71 \\
\hline Grid 7 & 3586,02 & 7 & 0,68 \\
\hline Grid 8 & 2954 & 3 & 0,66 \\
\hline Grid 9 & 1769,29 & 1 & 0,66 \\
\hline Grid 10 & 4199,7 & 3 & 0,66 \\
\hline
\end{tabular}

Elde edilen sonuçlar, karar vericilere analizin dinamik yapısı sayesinde yeni zincir market açmada, rakiplere göre mağaza konumlandırmada ve mevcut şubelerin pazar yamyamlığı (cannibalism) açısından arındırılması konularında yapılacak müteakip analizler için de altlık teşkil etmektedir. Yapılacak olan farklı puanlamalar ve kriterler ile firmaların stratejileri göz önünde bulundurularak daha doğru pazar analizi yapılmasının önemi ortaya konmuştur. Hızlı karar vermek isteyen firmalar tüm verileri toplamak için fazla zamanı yoksa, daha az önemli faktörleri göz ardı ederek çalışmalarını tamamlayabilirler. Ayrıntılı veri toplama ve kriterlerin farklılaştırılmasıyla daha doğru sonuçlar elde edilebilecektir.

Geliştirilen yöntemde, firmaların çeşitli şekillerde uymakla yükümlü olduğu kanunlar ve kurallar çerçevesinde (marketlerin içki satması camilerin etrafında yasak olması vb.) tekrar yeni kurallar eklenebilmekte ve sonuçlar optimize 
edilebilmektedir. Elde edilen diğer bir sonuç ise, İstanbul'daki mevcut zincir market dağılımının halihazırda yüksek potansiyel grid alan içinde yer almıs olduğudur. Genel olarak sonuçlar mevcut İstanbul'da bulunan zincir market potansiyelini ortaya koymaktadır.

Yeni şube açımında kullanılacak grid bazlı tematik haritaların oluşturulması sayesinde farklı bir bakış açısı ile karar vericilere Coğrafi Bilgi Teknolojilerinin önemi gösterilmektedir. Çalışma geleneksel yöntemlerle ortaya çıkan yanlış market yer seçimi sonucundaki oluşan maliyet kayıpları, müşteri potansiyeli, firma imajı ve rekabet edebilme gücü konularında firmaların avantaj sağlamasına katkıda bulunmaktadır. Çalışmamızda ortaya çıkan yüksek potansiyelli gridler ile kesişen ilçe ve mahallelerde zincir market firmalarının yatırım yapması, yeni şube açması ve mevcut şubelerin kapasitesinin artırılması konularında tavsiyeler sunulmuştur.

Geleneksel araştırmalarda ana konu yer seçimi problemlerindeki mesafeye odaklanılırken, bu çalışmada Nüfus, POI, Anket ve Yol Ağı verileri gibi çeşitli faktörler göz önünde bulundurulmuştur. Kullanılan verilerin çeşitliliği ve yoğunluğu dikkate alındığında, literatürde karşılaşılan çalışmalar içerisinde bu kadar çok kriterli ve kapsamlı veriyle yapılan ender çalışmalardan biri olma özelliğine sahiptir. Büyük veri ölçeğinde karar verme mekanizmaları literatürde az sayıda karşılaşılmıştır, kullandığımız veriler ile büyük veri ölçeğinde neler yapabileceğinin gösterilmesi açısından da ayrıca önemlidir.

Verilerin ölçeği büyüdükçe, girdi verilerin tutarlılığı önem kazanmaktadır. Bu çalışmada, verilerin kapsamlı olması yanında tutarlılık testleriyle beraber güvenilirliği de ortaya konulmuştur. Ayrıca AHP yöntemi ile hesaplanan sonuçlar ve haritalar TOPSIS yöntemi ile de hesaplanarak test edilip doğrulanmıştır. Normal koşullarda hesaplamanın ardından AHP yöntemine yeni kriterler eklemek ve puanları değiştirmenin zor olduğu koşulu bilgi teknolojilerinin kullanılması ile azaltılmış, yazılım altyapımızın dinamikliği nedeni ile bu kısım sorun olmaktan çıkmıştır.

Covid-19 süreci ile birlikte ortaya çıkan online satışların mevcut zincir marketler ve depolar üzerinden yönetildiği varsayıldığında, iyileştirmeleri yapmanın önemi bir kez daha ortaya çıkmaktadır. Yapılan çalışma sonuçları irdelendiğinde yer seçiminin artık perakende zincir marketler ve benzer diğer sektörler için ikna edici ve gerçeğe yakın olduğu görülmektedir. Çalışma ana odak olarak CBS'yi ortaya koymuş ve coğrafi analizlerin mikro ve makro ölçekteki işletmelerin karar verme süreçlerinde etkili olabildiği ve verimliliğini artırdığını göstermiştir. Türkiye'deki kentleşme ve nüfusun artması ile yerli ve yabancı kaynaklı yatırımların bilgi teknolojileri ve verilerin analizlerde kullanılması ile artacağı değerlendirilmektedir.

Analitik Hiyerarşi yöntemi yeni bir yöntem olmamakla birlikte, bu ölçekteki çalışmalar oldukça sınırlıdır. Çalışmanın, CBS kullanarak AHP yöntemi ile yer seçimi problemlerine kaynak olması ve ışık tutması beklenmektedir.

\section{Teşekkür}

Çalışmamızda anket verilerinin kullanımı konusunda yardımlarını esirgemeyen veri sağlayıcılarına teşekkür ederiz.

\section{Kaynaklar}

Alarcon,S.,2011. The Trade Credit in the Spanish AgroFood Industry. New Medit, 10(2), 51-57.

Arquero, A., Álvarez, M. and Martinez, E., 2009. Decision Management Making by AHP (Analytical Hierarchy Process) Trought GIS Data. Institute of Electrical and Electronics Engineers (IEEE) Latin America Transactions, 7, 101-106.

Atici, K. B., Şimşek A. B., Ulucan A. and Tosun M. U., 2015. A GIS-Based Multiple Criteria Decision Analysis Approach for Wind Power Plant Site Selection. Utilities Policy, 37, 86-96.

Bayar, R., 2005. CBS Yardımıyla Modern Alışveriş Merkezleri İçin Uygun Yer Seçimi : Ankara Örneği (Location Choice for Shopping Mall Centers Using GIS: Case Study of Ankara). Coğrafi Bilimler Dergisi/ Turkish Journal Geographical Sciences, 3(2), 19-38.

Bhushan, N., Rai, K., 2004. Strategic Decision Making: Applying the Analytic Hierarchy Process. SpringerVerlag, 172. 
Dožić, S., and Kalić M., 2014. An AHP Approach to Aircraft Selection Process. Transportation Research Procedia, 3, 165-74.

Gbanie, S. P., Tengbe P. B., Momoh J.S., Medo J., and Kabba V.T.S., 2013. Modelling Landfill Location Using Geographic Information Systems (GIS) and MultiCriteria Decision Analysis (MCDA): Case Study Bo, Southern Sierra Leone. Applied Geography, 36, 3-12.

Hernández T. and Bennison D., 2000. The Art and Science of Retail Location Decisions. International Journal of Retail \& Distribution Management, 28 (8), 357-67.

Karadeniz M., 2009. The Importance Of Retail Site Selection In Marketing Management And Hypothetical Approaches Used In Site Selection. The Importance of Retail Site Selection In Marketing Management And Hypothetical Approaches Used In Site Selection, 5(3), 79-90

Kayacan T. and Yirmibeşoğlu F., 2017. Site Selection Criteria for Sports Retail Sector: Istanbul Case. Current Urban Studies, 5(3), 290-304

Kuo, R. J., Chi, S. C. and Kao, S. S., 2002. A Decision Support System for Selecting Convenience Store Location through Integration of Fuzzy AHP and Artificial Neural Network. Computers in Industry, 47(2), 199-214.

Kuruüzüm, A., and Atsan N., 2001. Analitik Hiyerarşi Yöntemi ve İşletmecilik Alanındaki Uygulamaları (The Analytic Hierarchy Process Approach And It's Applications in Business). Akdeniz iktisadi ve Idari Bilimler Fakültesi (i.i.B.F.) Dergisi, 1, 83-105.

Ladle, J. K., Stiller D. and Stiller D., 2009. Retail Site Selection: A New, Innovative Model for Retail Retail Site Selection: A New, Innovative Model for Retail Development Development. Institute of Electrical and Electronics Engineers (IEEE) Latin America Transactions, 7, 101-106.

Mendes, A. B. and Themido, I. H., 2004. Multi-Outlet Retail Site Location Assessment. International Transactions in Operational Research, 11(1), 1-18.

Merunka, R. D., 2010. Sales Cannibalism. Wiley International Encyclopedia of Marketing.
Millet, I. and Wedley, W.C., 2002. Modelling Risk and Uncertainty with the Analytic Hierarchy Process. Journal of Multi-Criteria Decision Analysis, 11(2), 97107.

Monjezi, M., Dehghani, H., Singh, T. N., Sayadi, A.R. and Gholinejad, A., 2010. Application of TOPSIS Method for Selecting the Most Appropriate Blast Design. Arabian Journal of Geosciences, 5(1), 95-101.

Musyoka, S. M., Mutyauvyu, S. M., Kiema, J. B.K., Karanja, F. N., and Siriba, D. N., 2007. Market Segmentation Using Geographic Information Systems (GIS): A Case Study of the Soft Drink Industry in Kenya. Marketing Intelligence and Planning, 25 (6), 632-42.

Ozimec, A., Natter M. and Reutterer T., 2010. Geographical Information Systems-Based Marketing Decisions: Effects of Alternative Visualizations on Decision Quality. Journal of Marketing, 74 (6), 94110.

Rezaei-Moghaddam, K. and Karami E., 2008. A Multiple Criteria Evaluation of Sustainable Agricultural Development Models Using AHP. Environment, Development and Sustainability, 10 (4), 407-26.

Roig-Tierno, N., Baviera-Puig, A., Buitrago-Vera J. and Mas-Verdu, F., 2013. The Retail Site Location Decision Process Using GIS and the Analytical Hierarchy Process. Applied Geography, 40, 191-98.

Rybarczyk, G., and Wu C., 2010. Bicycle Facility Planning Using GIS and Multi-Criteria Decision Analysis. Applied Geography, 30 (2), 282-93.

Saaty, T. L., 1994. How to Make a Decision: The Analytic Hierarchy Process. Interfaces, 24 (6), 19-43.

Saaty, T. L., 2008. Decision Making with the Analytic Hierarchy Process - International Journal of Services Sciences - Volume 1, Number 1/2008 - Inderscience Publishers. International Journal of Services Sciences, 1 (1), 83-98.

Saaty, T. L. and Vargas, L. G., 2001. How to Make A Decision. 34, University of Pittsburgh, Springer Science+Business Media New York, 1-25.

Suárez-Vega, R., Santos-Peñate, D. R. and DortaGonzález, P., 2012. Location Models and GIS Tools for Retail Site Location. Applied Geography, 35 (1-2), 1222. 
Supçiller, A. A. and Çapraz, O.,2011. AHP-TOPSIS Yöntemine Dayalı Tedarikçi Seçimi Uygulaması. Istanbul Üniversitesi Iktisat Fakültesi Ekonometri ve istatistik Dergisi, 13, 1-22.

Şahin, E. K., 2010. Perakende Marketlerin Yer Seçimine Yönelik CBS Uygulaması. III. Uzaktan Algılama ve Coğrafi Bilgi Sistemleri Sempozyumu.

Şener, Ş., Şener, E., Nas, B. and Karagüzel, R. 2010. Combining AHP with GIS for Landfill Site Selection: A Case Study in the Lake Beyşehir Catchment Area (Konya, Turkey). Waste Management, 30 (11), 203746.

Şentürk, E., Livaoğlu, H., and Yavuz, E., 2017. Çok Kriterli Karar Analizi ile CBS Ortaminda En Uygun Spor Bayi Yer Seçimi İzmit Merkez Örneği. Uygulamalı Yerbilimleri Dergisi, 16 (1), 17-26.

Türkiye Alışveriş Merkezleri ve Perakendeciler Federasyonu (TAMPF), 2016. Dönüşürken Büyüyen Türkiye Perakende Sektörü Raporu. PricewaterhouseCoopers (PWC), 48-64.

Timor, M., 2011. Analitik Hiyerarşi Prosesi. Türkmen Kitabevi, İstanbul, 1, 1-304.

Uyan, M., 2013. GIS-Based Solar Farms Site Selection Using Analytic Hierarchy Process (AHP) in Karapinar Region Konya/Turkey. Renewable and Sustainable Energy Reviews, 28, 11-17.

Uygurtürk, H., 2012. Finansal Performansın TOPSIS Çok Kriterli Karar Verme Yöntemi İle Belirlenmesi: Ana Metal Sanayi İşletmeleri Üzerine Bir Uygulama. Eskişehir Osmangazi Üniversitesi iktisadi ve Idari Bilimler Fakültesi (iiBF) Dergisi, 7(2), 95-115.

Wang, L., Fan, H., and Wang, Y., 2018. Site Selection of Retail Shops Based on Spatial Accessibility and Hybrid BP Neural Network. ISPRS International Journal of Geo-Information, 7(6), 202.

Wei, J. (2010), TOPSIS Method for Multiple Attribute Decision Making with Incomplete Weight Information in Linguistic Setting. Journal of Convergence Information Technology, 5(10), 181-187.

Wind, Y. and Saaty, T. L.., 1980. Marketing Applications Of The Analytic Hierarchy Process. Management Science, 26(7), 641-58.
Wood, S. and Reynolds, J., 2012. Leveraging Locational Insights within Retail Store Development? Assessing the Use of Location Planners' Knowledge in Retail Marketing. Geoforum, 43(6), 1076-87.

Yang, J. and Lee, H., 2012. Leveraging Locational Insights within Retail Store Development? Assessing the Use of Location Planners' Knowledge in Retail Marketing. Geoforum, 43(6), 1076-87.

Yang, J. and Lee, H., 1997. An AHP Decision Model for Facility Location Selection. Facilities, 15(9-10), 24154.

Zeydan, M. and Kayserili, S., 2019. A Rule-Based Decision Support Approach for Site Selection of Automated Teller Machines (ATMs). Intelligent Decision Technologies, 13(2), 161-75.

\section{internet kaynakları}

1-http://www.ortakalan.org/gonderi/29378, (02.07.2020)

2-https://tr.euronews.com/2019/01/17/2019-kureselyasam-kalitesi-endeksi-istanbul-trafikte-en-fazla-zamankaybedilen-13-sehir, (21.08.2020)

3-https://www.basarsoft.com.tr/, (21.08.2020) 